\title{
Working
}

Paper 


\section{Country Stress Events: Does Governance Matter?}

Carlos Caceres and Anna Kochanova 
This page intentionally left blank 


\title{
IMF Working Paper
}

Middle East and Central Asia Department

\section{Country Stress Events: Does Governance Matter?*}

\author{
Prepared by Carlos Caceres and Anna Kochanova
}

Authorized for distribution by Mark Horton

May 2012

\section{This Working Paper should not be reported as representing the views of the IMF.}

The views expressed in this Working Paper are those of the author(s) and do not necessarily represent those of the IMF or IMF policy. Working Papers describe research in progress by the author(s) and are published to elicit comments and to further debate.

\begin{abstract}
This paper analyzes the linkages between governance quality and country stress events. It focuses on two types of events: fiscal and political stress events, for which two innovative stress indicators are introduced. The results suggest that weaker governance quality is associated with a higher incidence of both fiscal and political stress events. In particular, internal accountability, which measures the responsiveness of governments to improving the quality of the bureaucracy, public service provision, and respect for the institutional framework in place, is positively associated with fiscal stress events. However, external accountability, which captures government accountability before the public in general, through elections and the democratic process, seems to be more important for political stress events. These results hold when using balanced country samples where region, oil-exporter status, income level, and time are taken into account.
\end{abstract}

JEL Classification Numbers: A12, E02, E62, G38, K00.

Keywords: Governance; business environment; fiscal crises; political crises.

Author's E-Mail Addresses: ccaceres@imf.org, akochano@cerge-ei.cz.

\footnotetext{
* We would like to thank Alberto Behar, Vahagn Jerbashian, Tehmina Khan, Prachi Mishra, Sarah Sanya, Hans Weisfeld, and Jaejoon Woo, for constructive comments and discussions. In particular, Mark Horton and Nadeem Ilahi provided invaluable guidance and suggestions for this project. We are extremely grateful to Iva Petrova for having shared her dataset with us. We would also like to thank Kamal Krishna and Chunfang Yang for excellent research assistance. Any errors are solely the authors' responsibility.
} 


\section{Contents}

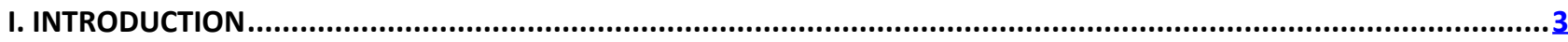

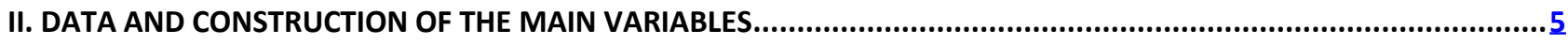

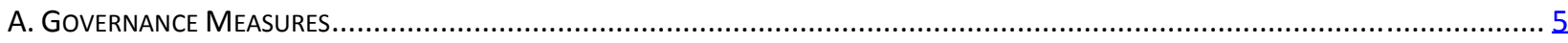

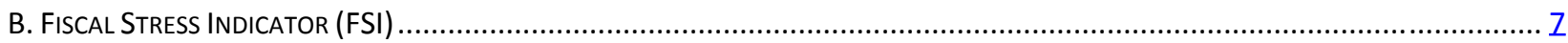

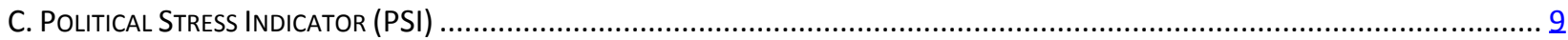

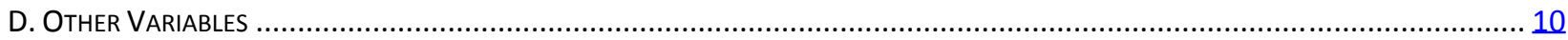

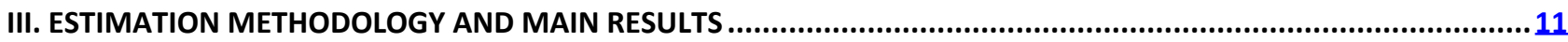

A. ESTIMATION TECHNIQUE

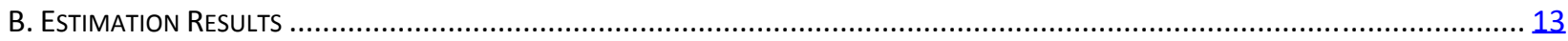

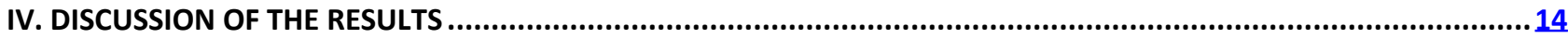

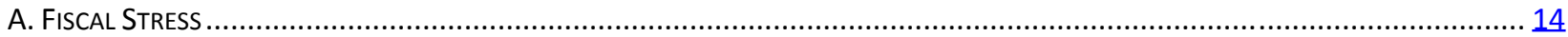

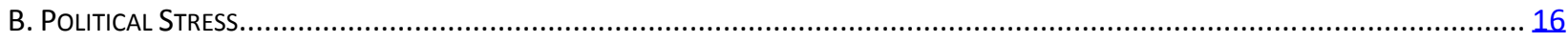

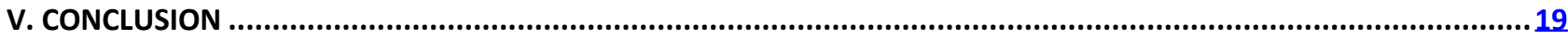

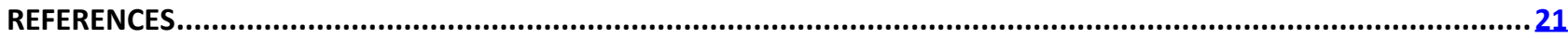

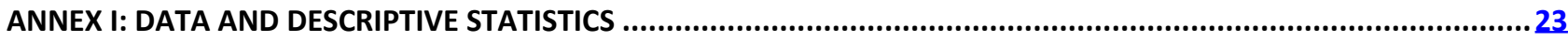

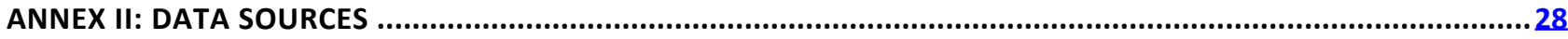

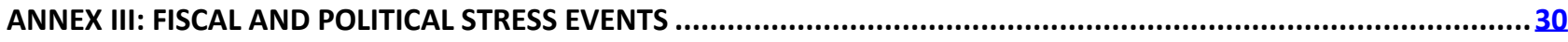

ANNEX IV: GROUPING OF COUNTRIES BY REGION AND HYDROCARBON EXPORT ....................................................

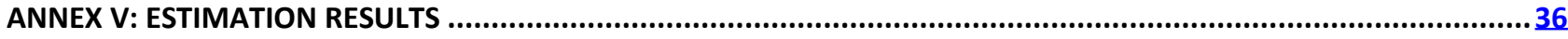

ANNEX VI: PREDICTED VALUES FROM STRESS EVENT MODEL..........................................................................40 


\section{INTRODUCTION}

Good governance plays an important role in implementing successful economic policies and sustaining inclusive growth. It provides transparency and predictability in policymaking, efficiency and equity in access to government services and resources, as well as equity in civil and political rights. Governance weaknesses, in turn, can involve onerous, ineffective and predatory regulatory procedures, and corruption that discourages entrepreneurial talent and undermines economic performance. They can also be reflected in poor public financial management, and, in the extreme, macroeconomic instability. Other associated concerns are weak tax policy or tax and custom administration, and excessive, wasteful, or poorly targeted public spending. Along with its inefficient policies and regulations, bad governance tends to restrict civil rights and freedoms, which may lead eventually to political instability and crises.

Recent events in different parts of the world provide examples of possible interrelations between governance quality and instability. The Arab Spring events of 2011 occurred in a region characterized by relatively weak governance and unequal access to the benefits from economic growth recorded in those countries.

Country stress events - fiscal, financial, balance of payments or even those that are political in nature - can develop into full-blown crises, with important adverse consequences for macroeconomic stability, such as a severe and permanent loss in output. There is a vast literature that analyzes the negative impact of such crises on the economy. Alesina et al. (1996) find that during periods of political instability, economic growth is significantly lower than at other times. ${ }^{1}$

This paper shows that the quality of governance matters for the incidence of fiscal and political stress events. We focus on these two types of stress events because they may be seen as occurring in areas generally under the control of the public sector or directly related to actions taken by policymakers. In this way, fiscal and political stress events differ from, for instance, financial crises, which tend to originate in actions and decisions made by private-sector agents. We expect that countries with weaker governance are more likely to be subject to fiscal and political stress events. An important contribution of this study is the identification of these stress events. We suggest a new methodology that helps to endogenously determine stress events; the events so determined seem to be less restrictive (or less arbitrary) than those usually used in the literature.

There are studies that consider a "fiscal stress event" to be characterized by instances of outright default or debt restructuring. ${ }^{2}$ Yet a country might experience severe fiscal stress, which could be reflected in significant constraints in their market access and increases in the cost of funding, long before default or restructuring occurs. Even if such stress does not ultimately result in debt default or restructuring, it may still have significant macroeconomic consequences. For example, a sharp increase in sovereign yields can significantly raise funding costs, debt-servicing costs, and roll-over

\footnotetext{
${ }^{1}$ See also Arellano (2008), Kaminsky and Reinhart (1996), Kaminsky et al. (1998), and Reinhart and Rogoff (2010), among others.

${ }^{2}$ For instance, Detragiache and Spilimbergo (2001) define public debt crises as events of outright default or rescheduling. Manasse et al. (2003) add the provision of a large-scale official financing support to the definition of a fiscal crisis.
} 
risk, but may also lead to a widespread increase in long-term interest rates in the rest of the economy, affecting both investment and consumption decisions. ${ }^{3}$ In other words, a more realistic measure of fiscal stress does not necessarily need to be characterized by outright public debt default and restructuring, but should include near-default events.

Similarly, other studies confine the definition of "political stress events" to cases of government collapse or regime change (say, from dictatorship to democracy). ${ }^{4}$ A country, however, may experience instances of increased "political stress," which can be characterized, for example, by an increase in the number of protests, anti-government demonstrations, riots, or street violence that could destabilize the effectiveness of the government and even the overall macroeconomic ambit, without necessarily leading to collapse of the government or a change of regime. These distinctions are captured in the stress measures that we develop.

Empirical research typically uses a "signaling" approach to attempt to identify the main variables that help to predict stress events. ${ }^{5}$ Although this method is transparent and easy to implement, it also seems to have important drawbacks. In particular, it ignores the possible interactions between the different explanatory variables, and does not allow standard inference and testing to assess the statistical validity of inclusion of variables in the model. There are also studies that use limited dependent variable estimation methodologies to quantify the link between a stress indicator and its determinants. ${ }^{6}$

In this study, we start with a simple comparison of average governance measures (and other relevant variables) between countries that undergo a stress event and those that do not, and test their statistical difference. Then we proceed with the same comparison but on a balanced sample, meaning that countries are combined into groups that share similar observed characteristics such as geographical region, income level, or hydrocarbon exporter status. We repeat this last step also grouping the data from a given year. After a comparison of averages, we estimate parsimonious conditional logistic regressions on the balanced sample to see whether governance measures have any predictive power, while controlling for other macroeconomic variables.

The results of the analysis suggest that countries with weaker governance tend to be more prone to political stress events. It is notable that statistically, the averages of all governance measures are different for the two groups of countries on a balanced sample (when region, oil, income level, and year are taken into account), while the averages of most of the other socio-economic variables are

\footnotetext{
${ }^{3}$ This can be illustrated by the current situation in the euro area. Indeed, several countries in the euro area periphery have been experiencing significant impairments to their access to funding during the past few years - with potential consequences for their macroeconomic stability. Yet, none of these countries have defaulted or restructured their debt during this period.
}

${ }^{4}$ For example, Alesina et al. (1996) define "political instability" as the propensity of a government to collapse. Dutt and Mitra (2008) define instances of political instability using movements between democratic and dictatorial regimes.

${ }^{5}$ The seminal papers by Kaminsky and Reinhart (1996) and Kaminsky et al. (1998) use the "noise-to-signal" ratio to determine which variables help to predict currency and banking crises. Baldacci et al. (2011) use the same approach to assess the determinant of episodes of fiscal stress.

\footnotetext{
${ }^{6}$ Manasse et al. (2003), for example, use logit and binary recursive tree analysis to identify macroeconomic variables that help to predict a debt-crisis episode one year in advance.
} 
not significantly different, except for real GDP growth, inflation, and trade openness. All governance measures remain significant in conditional logistic models when our political stress indicator is the dependent variable. In the case of fiscal stress events, however, only "governance effectiveness" and "control of corruption" seem to be associated with the incidence of fiscal stress events. These logistic models, however, should not be perceived as Early Warning Systems (due to their high persistence, governance measures embed relatively little information regarding the precise timing of a potential stress event taking place), but they are, rather, used as robustness checks vis-à-vis the comparison of the means on the balanced sample mentioned above.

Overall, this study confirms the importance of governance quality for the incidence of both political and fiscal stress events, although we do not infer a causal relationship between them. Policymakers, thus, should pay greater attention to improving governance in order to minimize the probability of stress events that can have severe consequences, damaging economic welfare and society as a whole.

This paper is organized as follows: Section II introduces the dataset and focuses on the construction of the governance, business environment, fiscal stress, and political stress measures. Section III presents the estimation methodology and empirical results, while Section IV assesses the main findings. Section V concludes the paper.

\section{DAta ANd Construction OF The Main VARIABLeS}

\section{A. Governance Measures}

To analyze the relationship between governance quality and stress events, and to determine which aspects of governance are more important, we use governance measures obtained from the World Bank's Worldwide Governance Indicators (WGI). ${ }^{7}$ The WGI database includes six broad measures of governance and the business environment: "control of corruption," "government effectiveness," "rule of law," "regulatory quality," "political stability and absence of violence," and "voice and accountability". Using a model of unobserved components, these indicators are constructed from perceptions-based cross-country surveys and expert opinions that come from more than 30 data sources. The indicators cover the period from 1996 to 2009, for about 200 countries.

The indicator for voice and accountability measures the degree to which citizens can participate in the selection of the government and hold it accountable through various aspects of political processes, civil liberties, and political rights. The political stability indicator relates to the probability of disposing of or destabilizing the government in a lawless or violent way, such that citizens are not able to select or remove it peacefully. These two indicators, in effect, describe the ability to hold the government accountable before the public through elections and voting processes, and broadly may be considered as a measure of "external accountability".

The government effectiveness indicator captures the quality and credibility of the bureaucracy and the provision of public services, and the competence of public officials to implement good policies

\footnotetext{
${ }^{7}$ These indicators are produced by the World Bank Institute, and were developed by Kaufmann et al. (1999). Kaufmann et al. (2010), for example, describe the data sources and the methodology for the construction of the indices.
} 
and to deliver public goods. The indicator for regulatory quality relates directly to the quality of public policies such as tendency to control prices, bank and business supervision, and other regulations. Government effectiveness and regulatory quality, therefore, are linked to the government's ability to create and implement good and fair policies.

The last two indicators measure the respect of both the public and the government for institutions that control interactions between them. Rule of law captures the incidence of crime, effectiveness of the judiciary, and enforcement of contracts. Finally, control of corruption measures perceptions of various aspects of corruption, from petty to grand corruption. These four indicators may be regarded as a measure of "internal accountability," in the sense that the government establishes various institutions and incentives to govern the behavior of agencies and agents within the state. ${ }^{8}$

All six governance indicators are highly correlated with each other as well as with income levels, measured by GDP per capita in PPP terms (Table 1, Annex I). The high correlation is not surprising, because governance aspects tend to be interrelated. For example, poor government efficiency and burdensome regulations may induce higher corruption. Richer and more developed countries historically tend to have better institutions. ${ }^{9}$ Furthermore, by construction some indicators share common data sources but with different weights, which naturally leads to higher correlation among indicators. To account for these correlations and to assess the broader aspects of governance quality, we consider also two aggregate indicators, reflecting external accountability and internal accountability, respectively, as described above. These two indicators, namely "external accountability (WGI)" and "internal accountability (WGI)" are obtained using principal component analysis (PCA).

The PCA procedure consists of searching for orthogonal linear combinations (principal components) of potentially correlated variables. The combination that produces the highest possible variation in the available data (in other words, absorbs the most information from the underlying variables) is called the first principal component. More precisely, the principal component is extracted as the eigenvector associated with the largest eigenvalue of the correlation matrix of the underlying variables. In theory, there can be as many principal components as the total number of variables. However, the practical idea behind PCA is to have one or a few components explaining a large portion of the total variance in the data. This renders the interpretation of the results relatively easy in any practical application. ${ }^{10}$ Since governance measures that constitute external and internal accountability share similar characteristics, construction of the first principal component is the best way (in comparison with simple averaging, for example) to preserve the highest variation in the data, which is essential for estimation purposes.

As a robustness check, we also employ several governance measures from the International Country Risk Guide (ICRG) rating agency. ${ }^{11}$ These measures are based on perceptions, and are constructed

\footnotetext{
${ }^{8}$ See also World Bank (2003) for a discussion of external versus internal accountability.

${ }^{9}$ See, for instance, Acemoglu et al. (2001).

${ }^{10}$ See Jollifee (2002) for a detailed discussion on the PCA methodology, and Behar (2009) and Caceres and Piperno Beer (2009) for practical applications of this methodology.
}

${ }^{11}$ A description of the data can be found at: http://www.prsgroup.com/ICRG_Methodology.aspx\#PolRiskRating. 
using opinions of experts only. The data cover a longer time period, from 1985 to 2011, but include a smaller number of countries. In our sample, ICRG indices cover about 30 fewer countries than WGI. We choose seven components out of twelve that comprise the ICRG political risk rating, group them into external and internal accountability as we have done with the WGI indicators, and combine them using PCA. Governance quality related to "external accountability (ICRG)" includes "democratic accountability," "internal conflict," and "military in politics"; and governance quality related to "internal accountability (ICRG)" involves "bureaucracy quality," "investment profile," "law and order," and "corruption". These components are similar to the WGI indicators, and are briefly described in Annex II. Correlations between these components and levels of income are high, but somewhat lower than in WGI (Table 1, Annex I).

Finally, and again as a robustness check, we use the Cross-National Time Series (CNTS) data archives $^{12}$ to construct a measure that relates to external accountability. In our sample the data range from 1970 to 2006 and cover only eight fewer countries than the WGI data. From CNTS we use five measures: "13 "type of regime," "effective executive (type)," "effective executive (selection)," "legislative effectiveness," and "legislative selection" (see Annex II for more details), and combine them into a single indicator, "external accountability (CNTS)," using principal component analysis. In comparison with WGI and ICRG indicators, this measure is less dependent on perceptions.

To make our governance measures more comparable with each other, we standardize them by taking their z-score, that is, we transform them into zero mean variables and unit standard deviation. Higher values indicate better governance quality. The descriptive statistics of these variables are presented in Table 2 (Annex I). The largest part of the variation in these governance measures is explained by cross-country (between standard deviation) variation. Figure 1 in Annex I shows the average values of the external and internal accountability indicators grouped by regions, income level, and oil-exporting status. Oil-exporting countries tend to have lower governance quality. Similarly, poorer countries have worse governance. The Middle East and North Africa and SubSaharan African regions also tend to have weaker governance quality than other regions; advanced countries significantly outperform all other regions (Annex IV describes the division of countries by region and oil-exporting status).

\section{B. Fiscal Stress Indicator (FSI)}

To identify episodes of "fiscal stress," we construct a Fiscal Stress Indicator (FSI), which takes values of 0 or 1 . FSI equals one when a country is under "fiscal stress" at a given year and zero otherwise.

The literature usually defines a fiscal stress event as an episode in which the sovereign defaults on its debt obligations - that is, default or restructuring of the debt. As noted, this definition seems restrictive because there are several instances in which countries experience stress for a prolonged

\footnotetext{
${ }^{12}$ Banks (2010) describes the CNTS data in detail.

${ }^{13}$ Original values of these measures have been slightly modified to satisfy the purposes of the paper. For example, all values have been rearranged so that higher value indicates better external accountability; "President" and "Premier" are combined together in "effective executive (type)"; "direct and indirect election" are also combined together in "effective executive (selection)".
} 
period of time (i.e., years) before default occurs, or, in some cases, without ever defaulting on its debt obligations. Fiscal stress can be visible when a country encounters difficulty in gaining normal access to funding. To broaden the definition, Manasse et al. (2003) add the provision of large-scale official financing support - measured as access to non-concessional IMF financing in excess of 100 percent of quota - to their measure of a fiscal stress event. Baldacci et al. (2011) further develop the definition of fiscal stress by including the concept of severe market-based financing constraint, or sovereign yield pressure, as indicated when sovereign spreads exceed 1000 basis points or two standard deviations from the country average. Although the inclusion of these innovations into the definition of stress events is welcome, the thresholds used in those studies may be seen as arbitrary, and are exogenous to the underlying characteristics of the data. In order to overcome this important shortcoming, we present a methodology in which the thresholds for the IMF financing and sovereign spreads are determined endogenously. Our measure of fiscal stress is constructed based on the following three steps:

(i) We take non-concessional IMF financing being accessed as a share of countries' quotas (referred to here as "IMF-financing") and sovereign spreads. Due to the lack of available consistent data for all countries, we employ three types of sovereign spreads. First, we use five-year sovereign swapspreads, which are available mainly for advanced countries and cover a maximum of 25 years. Second, we use EMBI blended spreads, which exist for about 30 emerging markets and cover a maximum of 18 years. Third, for other developing and low-income countries (around 15 countries in our sample) we use the spread of a country's 10-year sovereign bond yield relative to the 10-year US Treasury bond. For the remaining countries (mostly low-income), there are no spreads available or liquid enough to be used. As a result, we have four sets of countries that do not overlap each other according to availability of sovereign spread data.

(ii) For the three sets of countries with available sovereign spreads, we extract the first principal component from the IMF-financing and sovereign spreads using PCA. For those countries that do not have sovereign spreads, we use only IMF-financing, and transform them into a zero mean and unit standard deviation variable. This step results in four continuous variables, labeled $P C F_{i}$, for the four country groups $i=1,2,3,4$.

(iii) We use $P C F_{i}$ to compute a dichotomous Fiscal Stress Indicator. For this purpose we define thresholds $\tau_{i}$ such that when $P C F_{i}$ exceeds it $\left(P C F_{i} \geq \tau_{i}\right)$ we treat this situation as a fiscal stress event. Using each of the four $P C F_{i}$ separately, we try to predict the actual episodes of debt default or restructuring (based on the S\&P definition). ${ }^{14}$ The thresholds $\tau_{i}$ are defined as the level of $P C F_{i}$ at which the number of type I and type II errors of the prediction are equalized. A type I error (false positive) occurs when a statistical test rejects a true null hypothesis (an actual stress event occurring); while a type II error (false negative) occurs when the test fails to reject a false null hypothesis (an actual stress event is not occurring).

\footnotetext{
${ }^{14}$ There is one caveat with respect to defining the threshold for PCF in the case of advanced countries. Advanced countries have never defaulted (according to S\&P definition) within our sample period, in spite of some of them having had significant problems with sovereign debt. Therefore, we posited that Iceland experienced a "stress event" in 2008 and 2009 and Ireland, Portugal, and Greece in 2010 and 2011. Note, however, that the exclusion of these countries from the sample virtually does not change the results of the whole analysis. (These results are available from the authors upon request).
} 
This procedure yields an FSI that is endogenously determined and based on sovereign spreads and IMF-financing data. In other words, the construction of the FSI does not depend on an arbitrary choice made by the researcher. While constructing the threshold, we use actual default and restructuring episodes, since market interest rates tend to increase sharply before these events. Using the information on IMF-financing and/or spreads increase, we estimate the stress threshold, which is afterwards applied to countries not in default. The FSI, therefore, does not necessarily coincide perfectly with actual instances of default; rather, it captures stress reflected in the increase in IMF-financing and/or spread variables.

Table 1 in Annex III presents a list of stress event episodes captured by the FSI. According to the FSI measure, 16 percent of country-year observations are treated as stress episodes in our sample, ${ }^{15}$ partly reflecting the large number of IMF programs involving significant amounts of financing -in percent of quota - during our sample period (the same percentage is observed for defaults and debt restructuring). ${ }^{16}$ Figure 2 in Annex I presents empirical cumulative distribution functions for $P C F_{i}$ together with its medians and thresholds.

Figure 4 in Annex I shows the distribution of FSI by oil-exporting status, income quartiles, and region for two time periods, 1985-2011 and 1996-2011, since our governance measures from ICRG and WGI start from 1985 and 1996 respectively. Countries that are not oil exporters, and/or with lower income levels, tend to experience fiscal stress events more frequently. Countries from SubSaharan Africa are more often under fiscal stress than other regions.

\section{Political Stress Indicator (PSI)}

To characterize "political stress" events, the literature generally uses episodes of government collapse or transitions between nondemocratic and democratic regimes. However, a country might also experience significant political stress — marked, for example, by anti-government demonstrations, violence, riots, etc. - without necessarily implying an outright collapse of the government or a change in regime. This political stress, meanwhile, may reflect a general dissatisfaction of the public with, for example, inadequate governance, and may lead to socioeconomic dislocations, hindering macroeconomic stability and growth. In order to capture these notions of political stress, we construct an endogenous dichotomous measure, a Political Stress Indicator (PSI), which equals one when a country is in a situation of "political stress" in a given year, and equals zero otherwise. Using a similar methodology to that employed for the computation of the FSI, we construct the PSI based on the following three steps:

\footnotetext{
${ }^{15}$ This table represents a total number of 583 fiscal stress events, of which 10 took place in advanced economies and 573 in other countries over the period 1970-2011. The results can be compared, for example, with 41 and 135 fiscal stress events found in Baldacci et al. (2011) for advanced and emerging economies, respectively, over the period 19702010, and with 54 instances found in Manasse et al. (2003) which used a panel of market access countries over the period 1970-2002.

${ }^{16}$ Note that under the S\&P definition a country can be in "default" for several consecutive years until the country repays or reaches a settlement on its debt obligations, even if the country is no longer experiencing fiscal stress. In fact, this is one of the reasons why the FSI does not coincide with actual episodes of default or debt restructuring (as per the S\&P definition) for 65 percent of the cases.
} 
(i) From the CNTS database we take four variables: "major government crises," "purges," "revolutions," and "anti-government demonstrations". This dataset is based on counting the number of named events actually taking place (see Annex II for the details) and can potentially describe periods of political instability. The data cover about 175 countries over a century until 2008.

(ii) We extract the first principal component from these four variables using PCA, and refer to it as $P C P$.

(iii) We use $P C P$ to compute a dichotomous Political Stress Indicator. For this purpose we define a threshold $\tau$ such that when $P C P$ exceeds it $(P C P \geq \tau)$ we treat this situation as a political stress event. Using $P C P$ we try to predict actual episodes of regime change - that is, of transition from autocracy to democracy. These actual events are obtained from the "Democracy Dictatorship" database developed by Cheibub el al., 2009. The threshold $\tau$ is estimated as the level of PCP which equalizes the number of type I and type II prediction errors.

By analogy with the case of fiscal stress events, we expect that the incidence of government crises, purges, revolutions, and anti-government demonstrations increases significantly around periods of actual regime change. Table 2 in Annex III presents a list of political stress events signaled by the PSI. Episodes of political stress captured by the PSI and actual regime changes constitute only 2 percent of the whole sample, confirming that these are indeed 'rare' events. Figure 3 in Annex I presents empirical cumulative distribution functions for $P C P$ together with its median and threshold.

Political stress is thus defined as when the combination of the four variables embedded in $P C P$ exceeds the threshold $\tau$, independently of the values taken by these four variables separately. For example, we classify both Bolivia and Ecuador as being under political stress in 2005: the former experienced three government crises and four anti-government demonstrations, while the latter experienced two government crises, two purges, one revolution, and three anti-government demonstrations However, the $P C P$ (which is the combination of these four variables) exceeded the threshold $\tau$ for both countries in 2005 .

Figure 5 in Annex I shows the distribution of the PSI by oil-exporting status, income quartiles, and region for the time periods 1985-2008 and 1996-2008, as our governance measures from ICRG and WGI are defined over these two periods. Countries that are not oil exporters, and/or with income levels from the second and third quartiles (this suggests a nonlinearity with respect to development level), tend to experience political stress events more frequently. The same is true for countries from Latin America and, to a lesser extent, the Asia-Pacific region. During 1985-2008 Central and Eastern European countries experienced a relatively high number of political stress events, connected with the collapse of the Soviet Union and the socialist bloc.

\section{Other Variables}

Besides the various governance indicators, we employ other socioeconomic and demographic measures that can potentially be related to fiscal and political stress events. Nonetheless, it is important to emphasize that we are not trying to identify all possible relevant variables that can be associated with these stress events, but rather we use them to observe whether they are as important as the governance indicators in relation to stress events. In addition, we use some of these other 
variables as controls when estimating logistic models with the stress event indicators as dependent variable.

The first set of variables is related to fiscal stress events and includes standard budgetary aggregates, such as the overall fiscal balance, the public-debt-to-GDP ratio, and the share of total gross debt denominated in foreign currency. These variables are directly related to countries' fiscal pressure, and are commonly used in the literature on fiscal stress events. ${ }^{17} \mathrm{We}$ also include demographic variables such as the old-age dependency ratio and the fertility rate, which can be associated with long-term fiscal pressures.

The second set of variables that can be related to political stress events includes the following: unemployment rate and youth unemployment rate, education level, infant mortality rate, ${ }^{18}$ the poverty rate, the young-age dependency ratio, and inequality measures. For some variables data are available only for certain non-consecutive years. In those cases we interpolate the data to fill missing yearly observations. These variables describe country demographic structure, poverty, and economic environments that seem to be important for life satisfaction and welfare. For example, high youth unemployment, inequality, and poverty together with a high share of youth in the population, may lead to higher levels of dissatisfaction among the general public and increase the possibility of political stress or instability.

Finally, consumer price inflation, real GDP growth, and GDP per capita in PPP terms are included in both sets of variables to capture general macroeconomic conditions, as well as the level of economic development. All the variables employed, together with the governance measures, are considered at time $(t-1)$, while the stress (fiscal or political) variables are considered at time $t$, since we expect that the former should signal the incidence of a stress event before the event takes place. The definitions and data sources for these variables are presented in Annex II. Descriptive statistics and correlations among different variables are included in Tables 3-5 in Annex I.

\section{Estimation Methodology And Main Results}

\section{A. Estimation Technique}

To study the relationship between governance and stress events we proceed in two steps. First, we combine all countries into groups that share similar important characteristics. ${ }^{19}$ Within each group there are countries that are under "stress" and countries that are "stable" (i.e. not under

\footnotetext{
${ }^{17}$ See, for instance, Baldacci et al. (2011), and Manasse et al. (2003).

${ }^{18}$ Using a case-control methodology, Goldstone et al. (2010) find that infant mortality has a statistically significant effect on the incidence of episodes of adverse regime change and civil war.

${ }^{19}$ For this purpose we use the STATA command "cem," developed for the Coarsened Exact Matching (CEM) technique, see Iacus et al. (2009) and Iacus et al. (2011) for details. Although CEM and other matching techniques can be used for policy evaluation analysis and other purposes, we use it only for combining countries into groups and obtaining particular weights for observations to form a balanced sample. In general, classic matching techniques are somewhat limited for macroeconomic analysis because of the relatively small number of available country-year observations.
} 
stress). If a country that is under stress does not have a stable pair(s), it virtually drops out of the sample (in other words, it has zero weight in the analysis). Each country under stress receives a unit weight, and its stable matches receive weights uniformly distributed within a group. This procedure results in a balanced sample (that is, countries are grouped in strata, and each observation has a proper weight). Then we test whether the average value of our governance indicators and other relevant variables significantly differ, on the balanced sample, between countries that have experienced a stress event and those that have not.

Second, for completeness we extend our analysis by estimating logistic regressions on the balanced data to assess whether governance indicators have any predictive power for political and fiscal stress events conditional on other variables. These models should not be seen as an Early Warning System (EWS), because governance indicators - our main variables of interest - exhibit a high degree of persistence and explain mainly cross-country variation rather than variation over time.

The comparison of the variables' means for the stressed and stable countries on a balanced sample can be contrasted to a standard fixed-effect regression analysis with a number of fixed effects (region, income, oil, and year). Our approach has several advantages. First, fixed effect regressions require the inclusion of dummy variables and, more importantly, interactions among them to control for all fixed effects. ${ }^{20}$ These dummies consume a lot of degrees of freedom, which can lead to inefficient standard errors, and thus need to be adjusted. Second, in a balanced sample, more weight is assigned to groups with higher probability of having stress (higher share of "stressed" countries) and zero weight if such probability is zero, while linear regression gives more weight to cells where portions of "stressed" and "stable" countries are the same, which can create a bias (see, e.g., Angrist, 1998). Therefore, although the results from comparing the means on a balanced sample and using fixed-effect regression can be, in certain cases, relatively similar, our approach is more robust. Finally, estimation of regressions with country fixed effects may be inappropriate for governance measures, because the variation of these variables is explained mostly by cross-country differences. Fixed effects, thus, may account for all available variation, leaving no room for significance of the differences in the average levels of the governance variables between stressed and stable countries.

We start with a simple comparison of the means of the variables of interest for the two groups of countries: the countries that have experienced a stress event and those that have not. Then, we sequentially combine countries in groups that share such characteristics as region, hydrocarbon exporter status, income level, and year, and compare the means of the variables for the two groups of countries on the balanced sample. Annex III shows the division of all countries by region and hydrocarbon-exporting status. ${ }^{21}$ To divide countries by their income level, we create four categorical variables, each of which contains 25 percent of the observations sorted by GDP per capita in PPP terms. These categories can move for a country over time. For example, if we consider grouping by region, oil-exporting status and income, then we may have a maximum of $48(6 \times 2 \times 4)$ strata. The number of strata reduces if some of them do not contain countries that are under stress. In one of these strata, we compare, for example, stress years in Djibouti, Jordan, Pakistan, and Mauritania with stable years in other countries from the MENAP region, which are non-oil exporters, and with

\footnotetext{
${ }^{20}$ Simple fixed effects without interaction terms remove only average values that are associated with, for example, region and income level, but not those that are associated with region-income groups.

${ }^{21}$ As an exception, and given their relatively low number, we consider all the advanced countries in our sample as belonging to the same "region".
} 
an income from the second quartile. If we add the year dimension into the grouping, then we can only compare observations belonging to the same year.

Grouping by region allows us to control for regional characteristics, and implicitly controls - at least partially_-for important idiosyncratic characteristics (e.g., shared culture, common colonial history, similar population traits, or geographic dynamics) that tend to be persistent and generally associated with a given region. Similarly, we might expect that resource-rich countries within a given region would differ significantly from their non-hydrocarbon-exporting neighbors located in the same region. Resource-rich countries might be better able to finance government expenditures that reduce the probability of fiscal or political stress, in spite of relatively weak governance (see Figures in Annex I). Income level, measured by GDP per capita in PPP terms, is highly correlated with governance quality; richer countries tend to have better governance and business environments. The grouping of the countries along these factors 'strips out' the effect of important characteristics that could otherwise bias the results. Therefore, we expect that this selection of characteristics is able to capture the major macroeconomic differences between groups of countries, while maintaining a sufficient number of observations for the analysis.

As mentioned earlier, after comparing the means of the governance indicators and other variables, we estimate the following logistic model on the balanced data, separately for the two types of stress events:

$$
P\left(\operatorname{stress}_{i, t}=1\right)=\Lambda\left(\beta^{\prime} X_{i, t}\right)=\frac{\mathrm{e}^{\beta^{\prime} X_{i, t}}}{1+\mathrm{e}^{\beta^{\prime} X_{i, t}}}
$$

where $\operatorname{stress}_{i}$ is either fiscal or political stress event in a country $i, \Lambda(\cdot)$ denotes the logistic distribution function, $X$ is a vector containing the variables of interest and controls, and $\beta$ is a vector of parameters to be estimated. We use a logistic regression because it usually performs better if the limited dependent variable is not equally distributed, that is, if the number of 'zeros' differs greatly from (and far exceeds) the number of "ones". In the case of political stress events, for example, the number of "ones" only represents 10 percent of all observations - even on a balanced sample. The maximum likelihood estimation of a logistic regression is sensitive to the presence of heteroskedasticity. Thus, in spite of our data being relatively homogeneous in a balanced sample, we estimate the logistic regression with robust standard errors clustered on the level by which we group countries.

\section{B. Estimation Results}

The results of the comparison of the means for the two groups of countries are presented in Tables 1 and 2 in Annex V. Table 1 presents the results in the case of fiscal stress events, and Table 2 shows the results for political stress events. These two tables show the differences in the average levels of the variables of interest for the countries that have experienced a stress event and those that have not.

The comparison of the averages is repeated for the different groupings of countries mentioned earlier; these are based on income, region, hydrocarbon-exporter status, and year (each column in the tables represents a particular type of grouping). Therefore, we can observe how each type of matching (or grouping) affects the statistical significance of differences in the means, and which 
factors (e.g., geography, income level, hydrocarbon-exporting status) are more important to the relationship between governance indicators and stress events.

Tables 3 and 4 in Annex V present the results of the conditional logistic regression estimations (on the balanced sample), using the fiscal and political stress event measures as dependent variables. This exercise is done for completeness (and as a robustness check), and it allows us to test whether governance measures still have any predictive power on these stress events after controlling for some other relevant variables. These regressions include only those variables that, statistically, appear to be significantly different for countries that undergo a stress event and those that do not. We expect that only these variables could stay significant in these regressions (once several variables are simultaneously included); moreover, such parsimonious models allow us to preserve as many observations as possible. ${ }^{22}$

\section{Discussion OF The Results}

\section{A. Fiscal Stress}

The simple comparison of the means (that is, the comparison of the means before grouping) of the different governance measures shows that, on average, countries that have experienced a fiscal stress event tend to have worse governance than countries which have not experienced such an event (Table 1, Annex V). These results are statistically significant at the 1 percent level, and are relevant for all governance measures, except for our measure of "external accountability" from the CNTS database. The statistically significant difference in the means has also been found for other variables, such as income, real output growth, inflation, trade openness, and fiscal fundamentals. Essentially, countries that have experienced a fiscal stress event tend to have lower income per capita and higher inflation, and tend to be less open. As expected, they have a larger budget deficit, a higher debt-to-GDP ratio and a higher share of debt denominated in foreign currency. The signs of the differences in the means seem to be correct according to economic rationale. Nevertheless, a large part of the high statistical significance of these differences could be attributed to cross-country heterogeneity explained by, e.g., regional or income characteristics. For instance, richer countries, which exhibit better macroeconomic performance, tend to be less prone to stress events. Thus, comparing the average governance levels on the unbalanced sample does not allow us to determine whether the observed difference between stressed and stable countries is due to differences in governance quality or simply reflects income disparities, as both variables are highly correlated. In order to disentangle the effect of governance quality from that of income level (or that of geographical location and oil-exporting status), we repeat this analysis using the balanced sample instead.

Table 1 (columns II and III) shows the results of comparing the means when countries are grouped by region and oil-exporting status, and also by year. The averages of most variables are still statistically different for the two types of countries (i.e. "stressed" and "stable"), but the magnitude of the difference is smaller. This means that there is still significant variation among "stressed" and "stable" countries within regions. Grouping the different observations by year seems to be a more

\footnotetext{
${ }^{22}$ The full set of regressions on different balanced samples, with all set of governance measures among controls, are available from the authors upon request.
} 
important factor for the macroeconomic variables than for the governance indicators, because the latter tend to be much more persistent over time.

The inclusion of income level among the grouping characteristics changes the results dramatically (Table 1, columns IV and V). Now only "government efficiency" is significantly different (at the 5 percent significance level) for "stressed" and "stable" countries. ${ }^{23}$ Note that when controlling for the year, the significance level in the differences of some of the governance measures (mainly from the ICRG database) is reduced, probably because these variables cover a larger time period and present a higher variability. The differences in the means of the macroeconomic variables remain significant only for variables directly related to fiscal stance: budget balance, public-debt-to-GDP ratio, and the share of debt denominated in foreign currency.

These results indicate that income level (or development level), in particular, explains a large part of the differences between the countries that have experienced a fiscal stress event and those that have not. As noted, governance indicators are highly correlated with income level (see Annex I). Demographic indicators as well as inflation and openness can also be associated with income level. For example, richer countries tend to have older populations and a lower fertility rate, lower inflation rates and higher trade openness. However, this does not mean that income level is the only variable that matters in the incidence of fiscal stress events. It is notable, for example, that while several variables become insignificant once we control for income level, average values of "government effectiveness" (and, marginally, "control of corruption" and a couple of governance indicators from the ICRG database) are still statistically different for "stressed" and "stable" countries. This means that countries with weaker credibility and less efficient bureaucracy and public services provision together with higher corruption levels are more likely to experience fiscal stress events. The statistically significant difference in the means of fiscal variables for the two types of countries is not surprising, and it confirms the fact that fiscal fundamentals are indeed associated with the incidence of fiscal stress events.

The estimation of logistic regressions on a balanced sample, where countries are grouped according to their region, oil-exporting status, income level, and year, are presented in the Table 3 (Annex V). We include only "government effectiveness" and "control of corruption," as well as external and internal accountability measures computed using the WGI, ICRG, and CNTS databases. We use the budget balance and public debt-ratio as control variables. ${ }^{24}$

The results suggest that better "government effectiveness" and "control of corruption" are associated with a lower probability of experiencing a fiscal stress event. The same conclusion is relevant for the "internal accountability (WGI)" and "external and internal accountability (ICRG)" measures. The results show that both aspects of governance (internal and external accountability) matter in the incidence of fiscal stress events. ${ }^{25}$ As expected, variables related to fiscal stance are significant in almost all specifications.

\footnotetext{
23 "Control of corruption," "bureaucracy quality," "investment profile" and "external accountability (CNTS)," are marginally significant at the 15 percent level.

${ }^{24} \mathrm{We}$ do not consider the share of debt denominated in foreign currency in these regressions given the limited number of observations

${ }^{25}$ In fact, when the two measures of internal and external accountability from the ICRG database are included together in the regression, these appear to be jointly significant.
} 
The predicted values for the probability of a fiscal stress event taking place are presented for countries from six regions in Figures 1-6 in Annex VI. From these charts, we can see, for example, that the distribution of developed countries shifted to the right between the years 2004 and $2009 .{ }^{26}$ In other words, the number of advanced countries exhibiting a higher probability of fiscal distress increased over that time interval (Figure 6, Annex VI). Box 1 presents some examples of individual countries, and how the probabilities of experiencing a fiscal stress event have evolved over time in these countries.

In the case of emerging markets, the picture is more mixed. Overall, these countries did not experience - on average - a noticeable increase in the probability of having a fiscal stress event between 2004 and 2009. This confirms that the current fiscal stress period is more acute in advanced countries (particularly in the euro area). In fact, different groups of emerging and lowincome countries exhibit different behavior. For the Asia-Pacific and Middle Eastern and Central Asia regions, the probability of experiencing a fiscal stress event increased slightly between 2004 and 2009 (Figures 1 and 4, Annex VI). However, the same probability seems to have fallen for SubSaharan Africa over the same period (Figure 5, Annex VI).

\section{B. Political Stress}

In the case of political stress events, the results concerning governance measures are different from those obtained in the case of fiscal stress events. Thus, regardless of grouping criteria for balancing the sample, average values of almost all governance indicators are significantly different in countries that have experienced a political stress event from those that have not. Countries with worse governance seem to be more prone to experience political stress events. Only the "democratic accountability" and "bureaucracy quality" measures from the ICRG database are insignificantly different for the two types of countries. These results show that within a cell sharing the same region, oil-exporting status, income quartile, and year, there is still enough variation between "stressed" and "stable" countries, which can be largely attributed to differences in governance quality among these countries (Table 2, Annex V). It is thus notable that in spite of the high correlation between per capita income and governance measures, the latter still contain enough information (other than that embedded in per capita income) that can be associated with the incidence of political stress events.

Most of the socioeconomic variables included in our analysis are not significantly different between "stressed" and "stable" countries. This is true regardless of the matching characteristics used when combining the different countries into groups. Thus, region, oil-exporting status, income level, and year seem to explain most of the variation in these variables for the two types of countries. This can be explained by the fact that unemployment rates, level of education, infant mortality, demographic variables, poverty, and inequality are highly associated with the level of development or income per capita for both "stressed" and "stable" countries.

\footnotetext{
${ }^{26}$ Note that the predicted values for the probability of experiencing a stress event at time ' $t$ ' are calculated using data available up to time ' $t-1$ ', given that all explanatory variables are introduced with one lag .
} 


\section{Box 1: "Fiscal Stress" Model - Selected Country Examples}

A nonlinear model to estimate the probability of experiencing a fiscal stress event one year ahead was constructed based on the logistic regression results from Table 3 (Annex V). A logistic regression, including "government effectiveness" as a governance measure, is estimated on a balanced sample. Hence the predicted probabilities are implicitly conditioned on region, oilexporting status, income level, and year. The estimates of this model are used to predict the probabilities of having a stress event, for all the countries in our sample.

As an illustration, the charts below present the probability of fiscal distress occurring in selected euro area countries. ${ }^{27}$
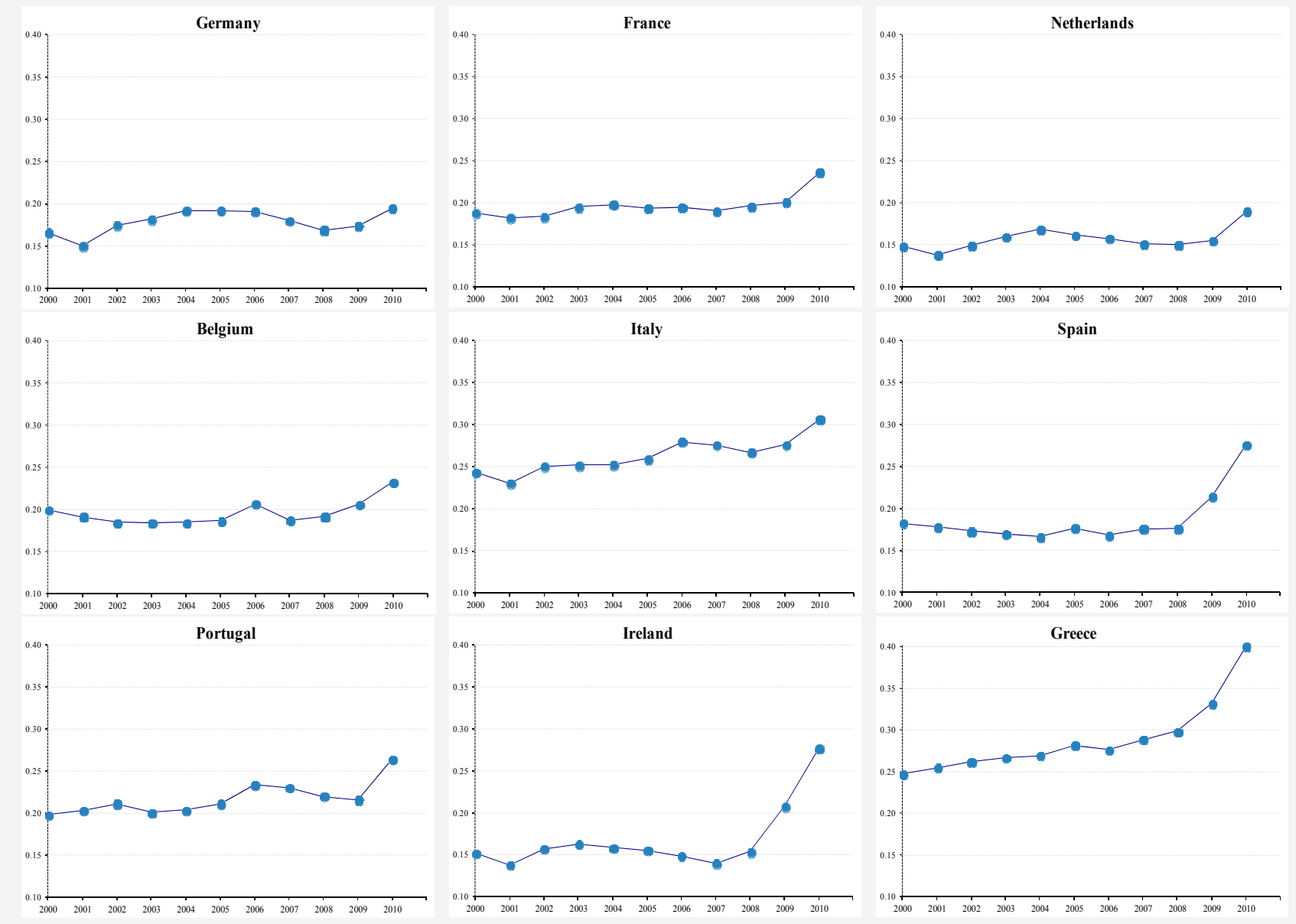

From these charts, it can be seen that the probability of experiencing a stress event has somewhat increased in most euro area countries over the last two years. In some, the observed increase which started in 2008 was already signaled a year earlier, even though the overall probability remained relatively modest (less than 40 percent). That said, the rise in the probabilities of a fiscal stress event

\footnotetext{
${ }^{27}$ Note that the value shown for every year $t$ corresponds to the value that was forecasted the year before (at $t--^{\prime}$ ) for that particular year $t$.
} 
occurring is very heterogeneous among these countries. Countries such as Germany and the Netherlands exhibited only a small increase (less than 5 percent) in these probabilities. Peripheral countries such Ireland and Greece were characterized by significant increases in their probability of experiencing a fiscal stress event (from around 15 to 28 percent, and from 30 to 40 percent, respectively).

However, it is important to note that most of the intratemporal variation in these stress probabilities comes from the variation in the fiscal variables included in our model. The governance measures explain mainly the differences in the average levels across countries. In other words, the governance measures can be seen as conveying information on whether a particular country is more likely - on average across time - than another country to experience a fiscal stress event. Yet, because of their relatively high persistence, these governance measures contain little information as to whether a given country is becoming (from one year to another) more or less likely to experience a fiscal stress event.

Macroeconomic variables such as GDP growth, inflation, and trade openness are significantly different between countries that have experienced a political stress event and those that have not. Countries with lower economic growth, higher inflation, and smaller trade openness tend to be more prone to experience political stress events. Therefore, poor macroeconomic performance may lead to a sharp increase in the discontent of the public, followed by unrest and, thus, a higher probability of political stress, which is consistent with the findings from the existing research. ${ }^{28}$

The estimation results from the logistic regressions on a balanced sample, where countries are grouped according to their region, oil-exporting status, income level, and year, are presented in Table 4 in Annex V. We include all the governance indicators from the WGI database as well as the external and internal accountability measures from the WGI, ICRG, and CNTS databases. As control variables we use real GDP growth, inflation, and trade openness.

The results suggest that better quality of governance is associated with a lower probability of experiencing a political stress event. Regarding the other controls, only real GDP growth and, in a few cases, inflation, are significantly associated with political stress events.

Figures 7-12 (Annex VI) show the distributions of predicted probabilities for the entire sample from the conditional logistic model with governance measure constructed as a first principal component from all six governance measures obtained from the WGI. We take the first principal component from these governance measures since they all appeared to have statistically significant association with the probability of having political stress. Figure 12 shows that the possibility of experiencing a political stress is much lower in advanced countries than in other regions (note the different scale in the horizontal axis). Furthermore, the probability of experiencing a stress event has increased (on average) for countries in Central and Eastern Europe, the Middle East, and

\footnotetext{
${ }^{28}$ For instance, Arezki and Bruckner (2011) find that, in low-income countries, increases in food prices lead to a significant deterioration of democratic institutions and a significant increase in political instability. See also Alesina et al. (1996) and Collier and Hoeffler (2004).
} 
Central Asia between 2004 and 2009 (Figure 8 and Figure 10, respectively) ${ }^{29}$, while it has fallen for Sub-Saharan African countries during the same period (Figure 11).

In conclusion, the main difference with the case of fiscal stress events is that governance measures tend to embed much more information related to the incidence of political stress events than is included in important country characteristics such as income, region, and oil-exporting status.

\section{Conclusion}

The main objective of this study is to analyze whether governance can be associated with stress events. In particular, two types of stress events are studied here: fiscal stress events and political stress events. For this purpose, we first construct two innovative indicators of fiscal and political stress.

Using these indicators to classify countries into those that experienced a stress event and those that have not (i.e. the 'controls'), we test whether governance quality-measured by governance indicators - in these two groups of countries is significantly different from a statistical point of view. We test these differences, grouping countries by important country characteristics, such as income, geographical region, the possession of hydrocarbon resources, and the year from which the observations are derived.

The results suggest that income levels play an important role in explaining the differences in governance quality between countries that have undergone a fiscal stress event and those that have not. Particularly, once income level is taken into account, only "governance effectiveness" and (marginally) "control of corruption" are significantly different for the two types of countries. Countries with higher corruption, inefficient bureaucracy, and burdensome public services provision, consequently, are more prone to fiscal stress events.

Nevertheless, governance quality seems to be better associated with political stress than with fiscal stress events. In particular, "external accountability," that is the ability to hold the government accountable before the public through election and voting processes, seems to be strongly associated with the incidence of political stress events. In fact, a country with a good macroeconomic performance (exhibiting, say, a strong and sustained output growth over a long period of time) is likely to be fiscally sustainable. However, if economic wellbeing does not benefit all segments of the population, nor address the general public's grievances and concerns regarding equality of opportunity or the fair application of the law (both of which can be linked to governance and political accountability), tensions may appear, and over time, lead to a political crisis.

\footnotetext{
${ }^{29}$ Although Figure 10 (Annex VI) shows that the probability of experiencing a political stress event increased in the Middle East and Central Asia region as a whole in the run-up to the "Arab Spring," this was mostly driven by a few Central Asian countries (e.g. the Kyrgyz Republic, Tajikistan ,and Turkmenistan) and Pakistan. In fact, apart from Libya, and to a lesser extent, Yemen (both of which experienced a temporary increase in the "political stress" probability in 2009), all other countries (including Bahrain, Egypt, Syria, and Tunisia) experienced no discernible change over that period, thus confirming our view that such models cannot be used as an early warning system.
} 
Furthermore, these results hold independently of the grouping criteria used throughout this paper. In other words, governance seems to matter in the incidence of political stress events, even when we control for the level of income, geographical location, and whether or not the country is a hydrocarbon exporter.

Finally, we estimate parsimonious conditional logistic regressions to assess the likelihood of a stress event taking place in a given country at every point in time for both types of stress events. The results from these models also confirm that weaker governance quality is associated with a higher probability of experiencing stress events. These models seem to have captured the increase in the probability of having a fiscal stress in the last couple of years, particularly in some of the euro area countries.

In summary, this study underscores the importance of improving the quality of governance, which seems to be associated with a lower incidence of both political and fiscal stress events. Thus, policymakers should pay greater attention to ways of strengthening governance and improving the institutional and business environment in which their countries operate. 


\section{REFERENCES}

Acemoglu D., S. Johnson, and J.Robinson (2001). "The Colonial Origins of Comparative Development: An Empirical Investigation," American Economic Review, 91 (5), pp. 13691401.

Alesina, A., S. Ozler, N. Roubini, and P.Swagel (1996). "Political instability and economic growth," Journal of Economic Growth, 1(2), pp. 189-211.

Angrist J.D. (1998). "Estimating the Labor Market Impact of Voluntary Military Service, Using Social Security Data on Military Applicants," Econometrica, 66(2), pp. 249-288.

Arellano, C. (2008). "Default Risk and Income Fluctuations in Emerging Economies," American Economic Review, 98 (3), pp. 690-712.

Arezki, R. and M. Bruckner, (2011). "Food Prices and Political Instability,” The Economic Research Forum, Working Paper 594

Baldacci, E., I.Petrova, N. Belhocine, G. Dobrescu, and S. Mazraani (2011). "Assessing Fiscal Stress," IMF Working Paper 11/100. (Washington, DC: International Monetary Fund)

Banks, A.S. (2010). User's Manual: Cross-National Time-Series Data Archive.

Behar, A. (2009). "Tax Wedges, Unemployment Benefits and Labour Market Outcomes in the New EU Members," AUCO Czech Economic Review, 3, pp. 69-92.

Caceres, C. and M. Piperno Beer (2008). "Analytical Framework for Assessing a Country's Macroeconomic and Financial Vulnerabilities," European Investment Bank-DEAS Working Paper No. 6.

Cheibub, J. A., J. Ganghi, and J. R. Vreeland (2009). "Democracy and dictatorship revisited," Public Choice, 143 (1), pp. 67-101.

Collier, P. and A.Hoeffler (2004). "Greed and Grievances in Civil Wars," Oxford Economic Papers, 56, pp. 563-95.

Detragiache, E. and A. Spilimbergo (2001). "Crises and Liquidity: Evidence and Interpretation," IMF Working Paper 01/2.

Dutt, P. and D.Mitra (2008). "Inequality and the Instability of Polity and Policy," Economic Journal, 118, pp. 1285-1314.

Goldstone, J., R. Bates, D. Epstein, T. Gurr, M. Lustik, M. Marshall, J. Ulfelder, and M. Woodward (2010). “A Global Model for Forecasting Political Instability," American Journal of Political Science, 54 (1), pp. 190-208.

Iacus, S. M., G. King, and G. Porro (2009). “CEM: Coarsened Exact Matching Software,” Journal of Statistical Software, 30. 
Iacus, S. M., G. King, and G. Porro (2011). "Multivariate Matching Methods That are Monotonic Imbalance Bounding," American Statistical Association, 106, 493.

Jolliffee, I. (2002). “Principal Component Analysis,” $2^{\text {nd }}$ edition, New York, Springer.

Kaminsky, G. and C. M. Reinhart (1996). "The Twin Crises: The Causes of Banking and Balanceof-Payments Problems," American Economic Review, 89 (3), pp. 473-500.

Kaminsky, G., S. Lizondo, and C.M. Reinhart (1998). "Leading Indicators of Currency Crises," IMF Staff Papers, 45, 1, pp. 1-48.

Kaufnamn, D. and Kraay, A. (2002). “Growth without Governance,” Economia, 3 (1), pp. 169-229.

Kaufmann, D., A. Kraay, and M. Mastruzzi (2010). "The Worldwide Governance Indicators:

Methodology and Analytical Issues,” World Bank Policy Research Working Paper No 5430.

Kaufmann, D., A. Kraay, and P. Zoido-Lobaton (1999). “Aggregating governance indicators,” World Bank Policy Research Working Paper No 2195.

Manasse, P., N. Roubini, and A. Schimmelpfennig (2003). "Predicting Sovereign Debt Crises," IMF Working Paper 03/221.

Reinhart, C.M and K.S. Rogoff (2010). "Growth in a Time of Debt," American Economic Review, 100(2), pp. 573-578.

World Bank (2003). "Better Governance for Development in the Middle East and North Africa: Enhancing Inclusiveness and Accountability," Washington DC: World Bank. 


\section{ANNEX I: DATA AND DESCRIPTIVE STATISTICS}

Table 1: Pairwise correlations between governance indicators

\begin{tabular}{|c|c|c|c|c|c|c|c|c|c|c|c|c|}
\hline & & 1 & 2 & 3 & 4 & 5 & 6 & 7 & 8 & 9 & 10 & 11 \\
\hline 1 & Voice \& Accountability & & & & & & & & & & & \\
\hline 2 & Political Stability & $0.71 *$ & & & & & & & & & & \\
\hline 3 & Government Effectiveness & $0.80 *$ & $0.75^{*}$ & & & & & & & & & \\
\hline 4 & Regulatory Quality & $0.81 *$ & $0.70 *$ & $0.92 *$ & & & & & & & & \\
\hline 5 & Rule of Law & $0.81 *$ & $0.81 *$ & $0.95 *$ & $0.89 *$ & & & & & & & \\
\hline 6 & Control of Corruption & $0.78^{*}$ & $0.76^{*}$ & $0.94 *$ & $0.87^{*}$ & $0.94 *$ & & & & & & \\
\hline 7 & External Accountability (WGI) & $0.93 *$ & $0.93 *$ & $0.84 *$ & $0.82 *$ & $0.88^{*}$ & $0.83 *$ & & & & & \\
\hline 8 & Internal Accountability (WGI) & $0.83^{*}$ & $0.78^{*}$ & $0.98^{*}$ & $0.95^{*}$ & $0.98^{*}$ & $0.97 *$ & $0.87 *$ & & & & \\
\hline 9 & External Accountability (ICRG) & $0.86^{*}$ & $0.81 *$ & $0.78^{*}$ & $0.77^{*}$ & $0.79 *$ & $0.74 *$ & $0.90 *$ & $0.79 *$ & & & \\
\hline 10 & Internal Accountability (ICRG) & $0.77^{*}$ & $0.77 *$ & $0.92 *$ & $0.87^{*}$ & $0.93 *$ & $0.92 *$ & $0.83 *$ & $0.94 *$ & $0.81 *$ & & \\
\hline 11 & External Accountability (CNTS) & $0.59 *$ & $0.34 *$ & $0.35 *$ & $0.42 *$ & $0.34 *$ & $0.31 *$ & $0.51 *$ & $0.36^{*}$ & $0.51 *$ & $0.36^{*}$ & \\
\hline 12 & GDP per capita & $0.63^{*}$ & $0.65^{*}$ & $0.81 *$ & $0.76^{*}$ & $0.78 *$ & $0.76^{*}$ & $0.70^{*}$ & $0.80^{*}$ & $0.66^{*}$ & $0.74 *$ & $0.29 *$ \\
\hline
\end{tabular}

* stands for significance at the 1 percent level.

Table 2: Descriptive statistics of governance measures (mean $=0$, overall std. dev.=1)

\begin{tabular}{|c|c|c|c|c|c|}
\hline \multirow[t]{2}{*}{ Variable } & \multirow[t]{2}{*}{ Observations } & \multicolumn{2}{|c|}{ Standard Deviation } & \multirow[t]{2}{*}{ Minimum } & \multirow[t]{2}{*}{ Maximum } \\
\hline & & Between & Within & & \\
\hline Voice \& Accountability & 2496 & 0.98 & 0.19 & -2.17 & 1.97 \\
\hline Political Stability & 2465 & 0.95 & 0.31 & -3.07 & 1.73 \\
\hline Government Effectiveness & 2426 & 0.98 & 0.20 & -2.41 & 2.35 \\
\hline Regulatory Quality & 2454 & 0.97 & 0.25 & -2.90 & 3.48 \\
\hline Rule of Law & 2467 & 0.98 & 0.20 & -2.28 & 2.09 \\
\hline Control of Corruption & 2429 & 0.97 & 0.22 & -2.45 & 2.51 \\
\hline External Accountability (WGI) & 2465 & 0.97 & 0.23 & -2.66 & 1.94 \\
\hline Internal Accountability (WGI) & 2424 & 0.98 & 0.17 & -2.26 & 2.27 \\
\hline Democratic Accountability & 3490 & 0.85 & 0.54 & -2.32 & 1.36 \\
\hline Internal Conflict & 3491 & 0.73 & 0.68 & -3.55 & 1.25 \\
\hline Military in Politics & 3492 & 0.89 & 0.44 & -2.09 & 1.24 \\
\hline Bureaucracy Quality & 3493 & 0.90 & 0.43 & -1.85 & 1.58 \\
\hline Investment Profile & 3494 & 0.63 & 0.78 & -2.90 & 1.84 \\
\hline Law \& Order & 3495 & 0.85 & 0.52 & -2.52 & 1.58 \\
\hline Corruption & 3496 & 0.83 & 0.55 & -2.26 & 2.24 \\
\hline External Accountability (ICRG) & 3497 & 0.87 & 0.49 & -3.12 & 1.52 \\
\hline Internal Accountability (ICRG) & 3498 & 0.91 & 0.39 & -2.73 & 2.22 \\
\hline External Accountability (CNTS) & 5716 & 0.72 & 0.68 & -3.43 & 0.77 \\
\hline
\end{tabular}

Note: This statistics are reported for the entire available sample. When analyzing fiscal and political stress events we use two different and somewhat smaller samples. However, The main descriptive statistics for these are similar. 
Figure 1: Average values of External and Internal Accountability (WGI), by categories
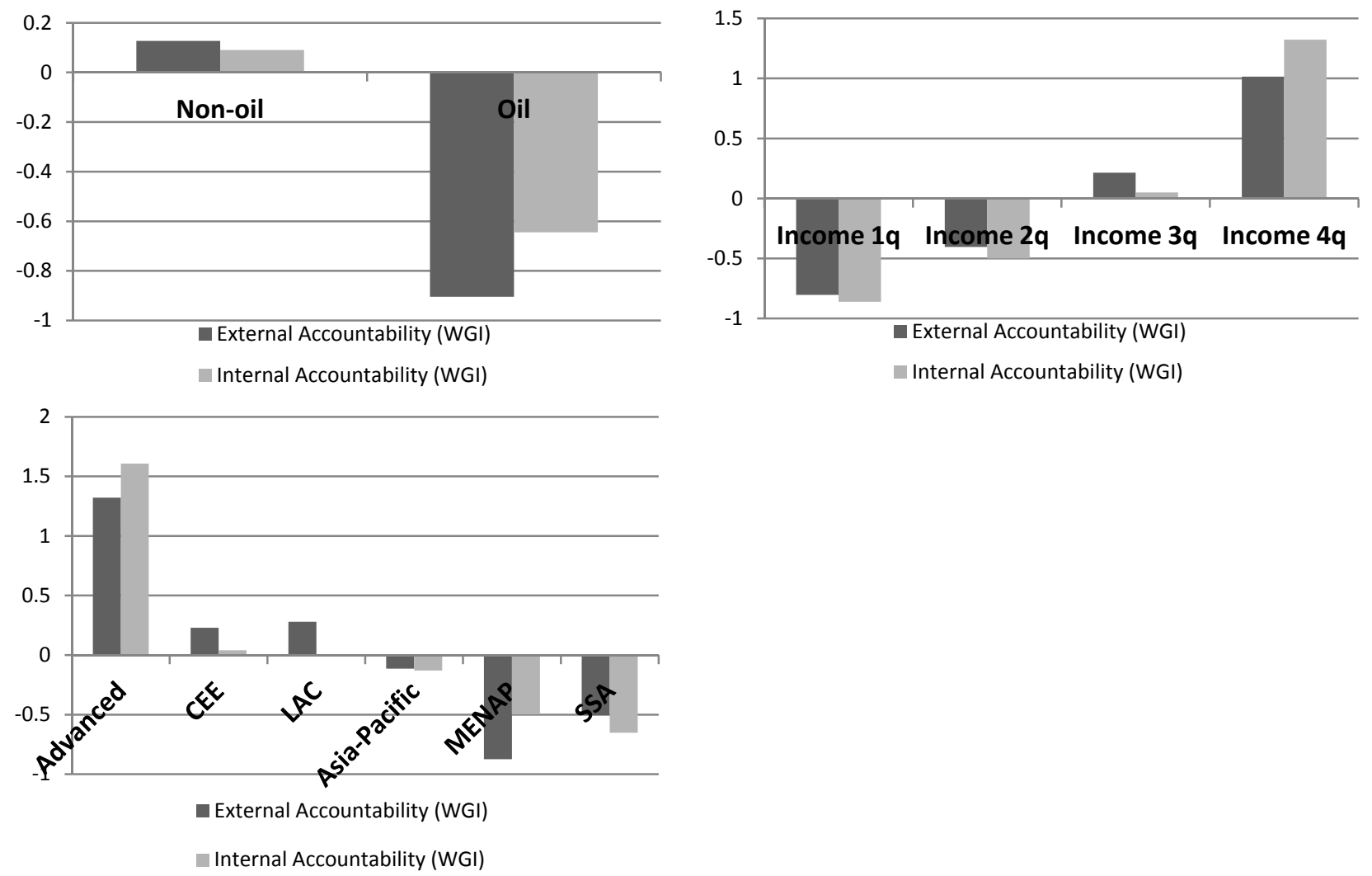

Note: $1 \mathrm{q}$ is the lowest quartile and $4 \mathrm{q}$ is the highest quantile

Table 3: Descriptive statistics of employed variables

\begin{tabular}{lccccccc}
\hline \multirow{2}{*}{ Variable } & \multirow{2}{*}{ Observations } & \multirow{2}{*}{ Mean } & \multicolumn{3}{c}{ Standard Deviation } & \multirow{2}{*}{ Minimum } & \multirow{2}{*}{ Maximum } \\
\cline { 3 - 6 } & & & & Overall & Between & Within & \\
\hline GDP per capita & 6368 & 8.45 & 1.28 & 1.23 & 0.32 & 5.46 & 11.82 \\
Real GDP growth & 6432 & 3.58 & 5.55 & 1.77 & 5.29 & -37.51 & 36.80 \\
Inflation & 6271 & 12.86 & 28.97 & 14.69 & 25.96 & -19.41 & 353.61 \\
Openness & 6062 & 4.20 & 0.70 & 0.59 & 0.36 & -1.65 & 7.13 \\
Balance & 3496 & -0.02 & 0.07 & 0.04 & 0.06 & -1.51 & 0.58 \\
Debt-ratio & 2771 & 0.65 & 0.73 & 0.54 & 0.51 & 0.00 & 13.19 \\
Share of FCD debt & 972 & 0.62 & 0.27 & 0.24 & 0.11 & 0.00 & 1.12 \\
Age dependency (old) & 6667 & 10.15 & 6.02 & 5.84 & 1.55 & 1.25 & 33.92 \\
Fertility rate & 6608 & 4.00 & 1.98 & 1.75 & 0.91 & 0.90 & 8.73 \\
Unemployment & 3218 & 8.60 & 6.38 & 7.80 & 3.03 & 0.00 & 59.50 \\
Youth Unemployment & 2038 & 16.60 & 9.61 & 11.14 & 4.43 & 0.70 & 69.22 \\
Schooling & 4729 & 6.95 & 3.02 & 2.85 & 1.19 & 0.12 & 13.27 \\
Infant Mortality & 2735 & 38.93 & 40.58 & 37.93 & 17.39 & 1.80 & 214.10 \\
Age dependency (young) & 6667 & 62.41 & 23.95 & 21.88 & 9.85 & 15.95 & 112.38 \\
Population growth & 6905 & 1.77 & 1.65 & 1.20 & 1.13 & -44.41 & 17.74 \\
Poverty gap & 1743 & 9.69 & 12.17 & 12.12 & 3.84 & 0.00 & 63.34 \\
High income share & 1677 & 32.86 & 7.21 & 7.63 & 2.68 & 15.44 & 65.00 \\
GINI & 1677 & 41.77 & 9.55 & 9.73 & 3.21 & 19.40 & 74.33 \\
\hline
\end{tabular}


Table 4: Pairwise correlations between FSI, governance indicators, and other variables

\begin{tabular}{lcccc} 
& FSI & Default (S\&P) & External Accountability (WGI) & Internal Accountability (WGI) \\
\hline Default (S\&P) & $0.22^{*}$ & & & \\
External Accountability (WGI) & $-0.18^{*}$ & $-0.23^{*}$ & & $0.87^{*}$ \\
Internal Accountability (WGI) & $-0.25^{*}$ & $-0.29^{*}$ & $0.90^{*}$ & $0.80^{*}$ \\
External Accountability (ICRG) & $-0.23^{*}$ & $-0.45^{*}$ & $0.85^{*}$ & $0.95^{*}$ \\
Internal Accountability (ICRG) & $-0.27^{*}$ & $-0.42^{*}$ & $0.56^{*}$ & $0.45^{*}$ \\
External Accountability (CNTS) & -0.02 & $-0.07^{*}$ & $0.75^{*}$ & $0.87^{*}$ \\
GDP per capita & $-0.26^{*}$ & $-0.28^{*}$ & $-0.12^{*}$ & $-0.12^{*}$ \\
Real GDP growth & -0.03 & $-0.14^{*}$ & $-0.31^{*}$ & $-0.31^{*}$ \\
Inflation & $0.07^{*}$ & $0.23^{*}$ & $0.29^{*}$ & $0.26^{*}$ \\
Openness & $-0.10^{*}$ & $-0.21^{*}$ & $0.12^{*}$ & $0.14^{*}$ \\
Balance & $-0.11^{*}$ & $-0.08^{*}$ & $-0.23^{*}$ & $-0.23^{*}$ \\
Debt-ratio & $0.17^{*}$ & $0.33^{*}$ & $-0.20^{*}$ & $-0.37^{*}$ \\
Share of FCD debt & $0.21^{*}$ & $0.32^{*}$ & $0.70^{*}$ & $0.75^{*}$ \\
Age dependency (old) & $-0.16^{*}$ & $-0.22^{*}$ & $-0.59^{*}$ & $-0.66^{*}$ \\
Fertility rate & $0.12^{*}$ & $0.23^{*}$ & \\
\hline
\end{tabular}

* stands for significance at the 1 percent level.

Table 5: Pairwise correlations between PSI, governance indicators, and other variables

\begin{tabular}{lcccc} 
& PSI & Regime change & External Accountability (WGI) & Internal Accountability (WGI) \\
\hline Regime change & $0.07^{*}$ & & & \\
External Accountability (WGI) & $-0.10^{*}$ & $-0.12^{*}$ & & $0.87^{*}$ \\
Internal Accountability (WGI) & $-0.07^{*}$ & $-0.10^{*}$ & $0.90^{*}$ & $0.83^{*}$ \\
External Accountability (ICRG) & $-0.08^{*}$ & $-0.14^{*}$ & $0.51^{*}$ & $0.94^{*}$ \\
Internal Accountability (ICRG) & $-0.08^{*}$ & $-0.11^{*}$ & $0.70^{*}$ & $0.36^{*}$ \\
External Accountability (CNTS) & $-0.07^{*}$ & $-0.09^{*}$ & $-0.10^{*}$ & $0.80^{*}$ \\
GDP per capita & -0.02 & $-0.08^{*}$ & $-0.27^{*}$ & $-0.10^{*}$ \\
Real GDP growth & $-0.07^{*}$ & $-0.03^{*}$ & $0.26^{*}$ & $-0.28^{*}$ \\
Inflation & $0.04^{*}$ & 0.02 & $-0.18^{*}$ & $0.21^{*}$ \\
Openness & $-0.10^{*}$ & $-0.04^{*}$ & $-0.14^{*}$ & $-0.24^{*}$ \\
Unemployment & -0.01 & -0.01 & $0.57^{*}$ & $-0.22^{*}$ \\
Youth Unemployment & 0.01 & -0.01 & $-0.67^{*}$ & $0.62^{*}$ \\
Schooling & $-0.04^{*}$ & $-0.06^{*}$ & $-0.60^{*}$ & $-0.71^{*}$ \\
Infant Mortality & 0.03 & $0.05^{*}$ & $-0.38^{*}$ & $-0.68^{*}$ \\
Age dependency (young) & 0.02 & $0.06^{*}$ & $-0.37^{*}$ & $-0.31^{*}$ \\
Population growth & 0.01 & 0.02 & $-0.11^{*}$ & $-0.43^{*}$ \\
Poverty gap & -0.01 & $0.09^{*}$ & -0.06 & $-0.10^{*}$ \\
High income share & 0.03 & -0.02 & -0.02 & $-0.07^{*}$ \\
GINI & 0.03 & &
\end{tabular}

* stands for significance at the 1 percent level. 
Figure 2: Components $\left(P C F_{i}\right)$ and thresholds for computing Fiscal Stress Indicator
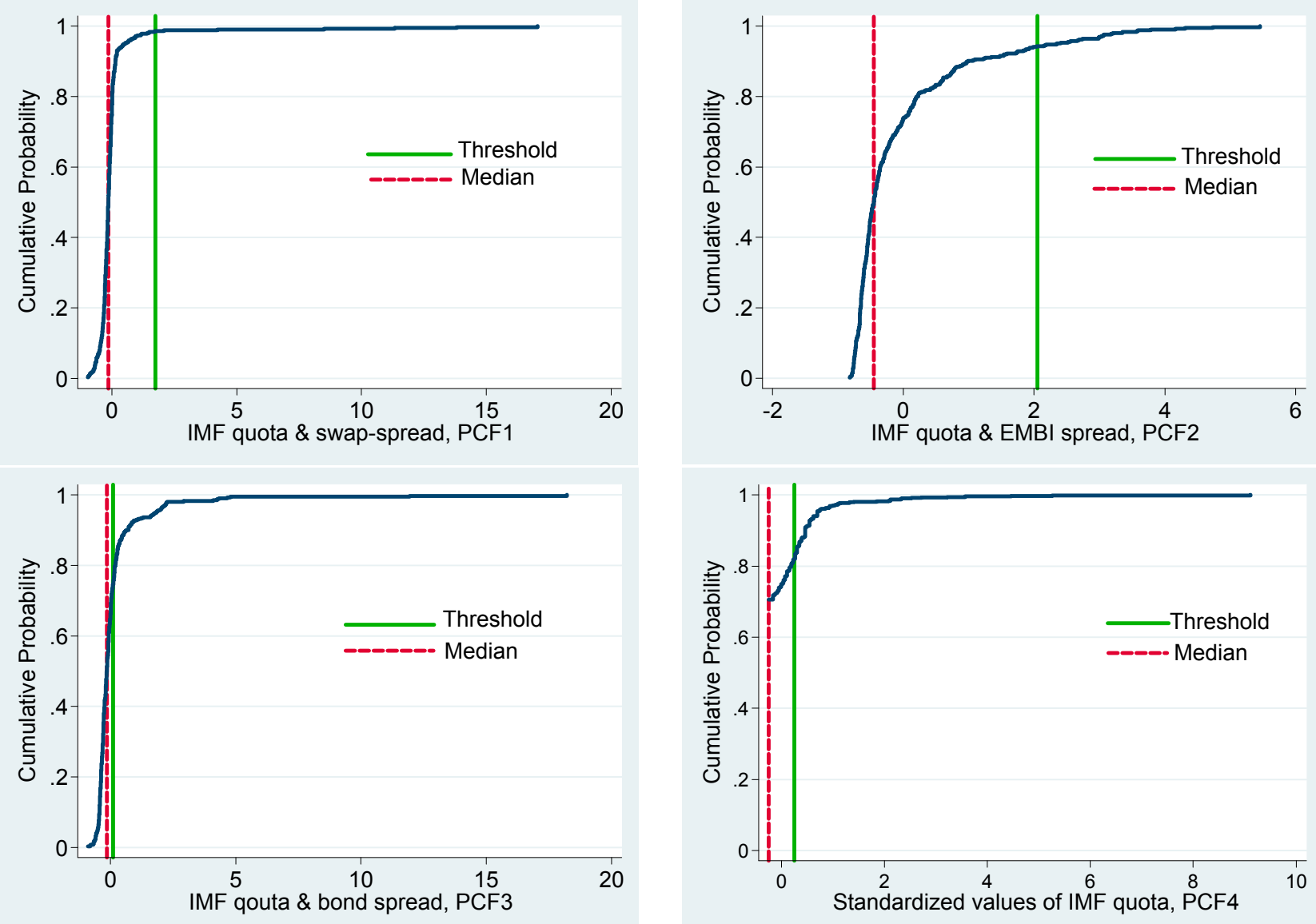

Figure 3: $P C P$ and threshold for computing Political Stress Indicator

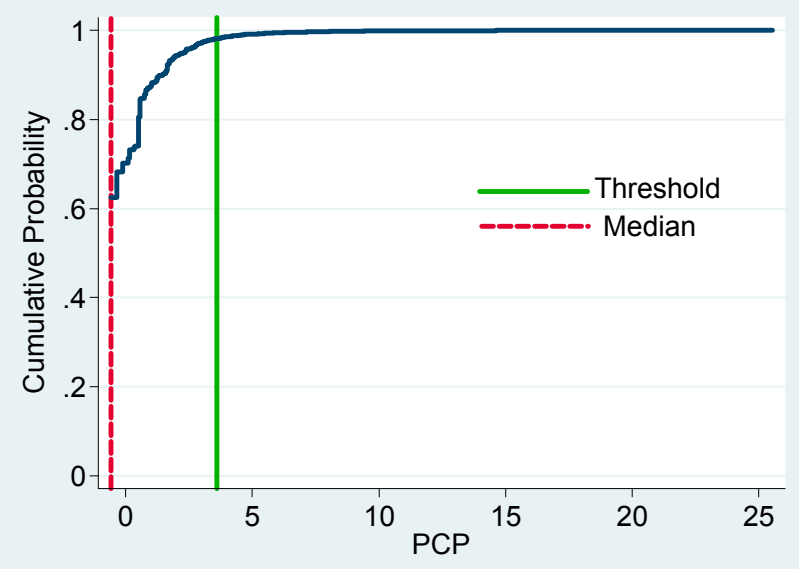


Figure 4: Frequencies of Fiscal Stress Index, by categories
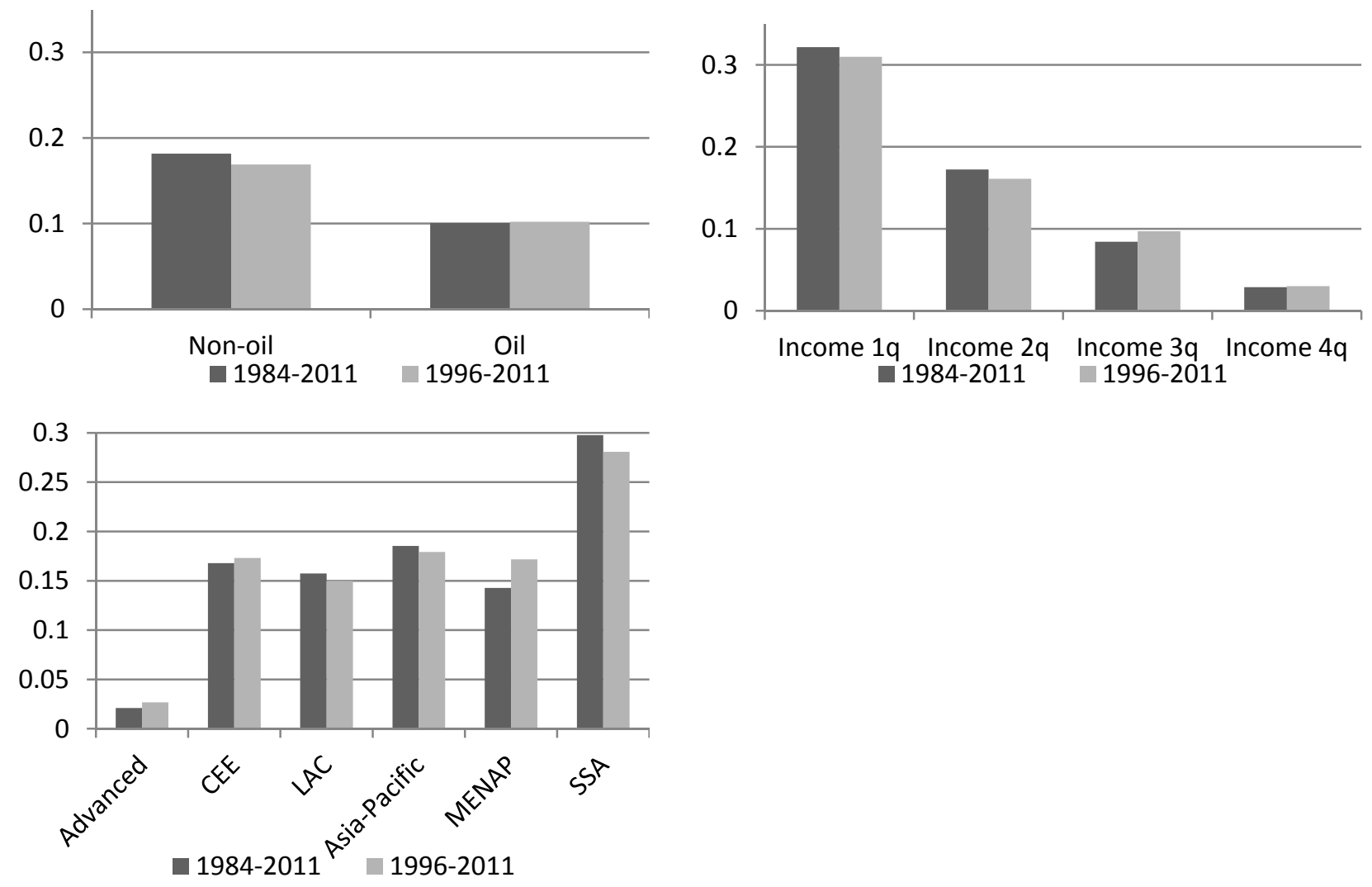

Note: 1q is the lowest quartile and $4 \mathrm{q}$ is the highest

Figure 5: Frequencies of Political Stress Index, by categories
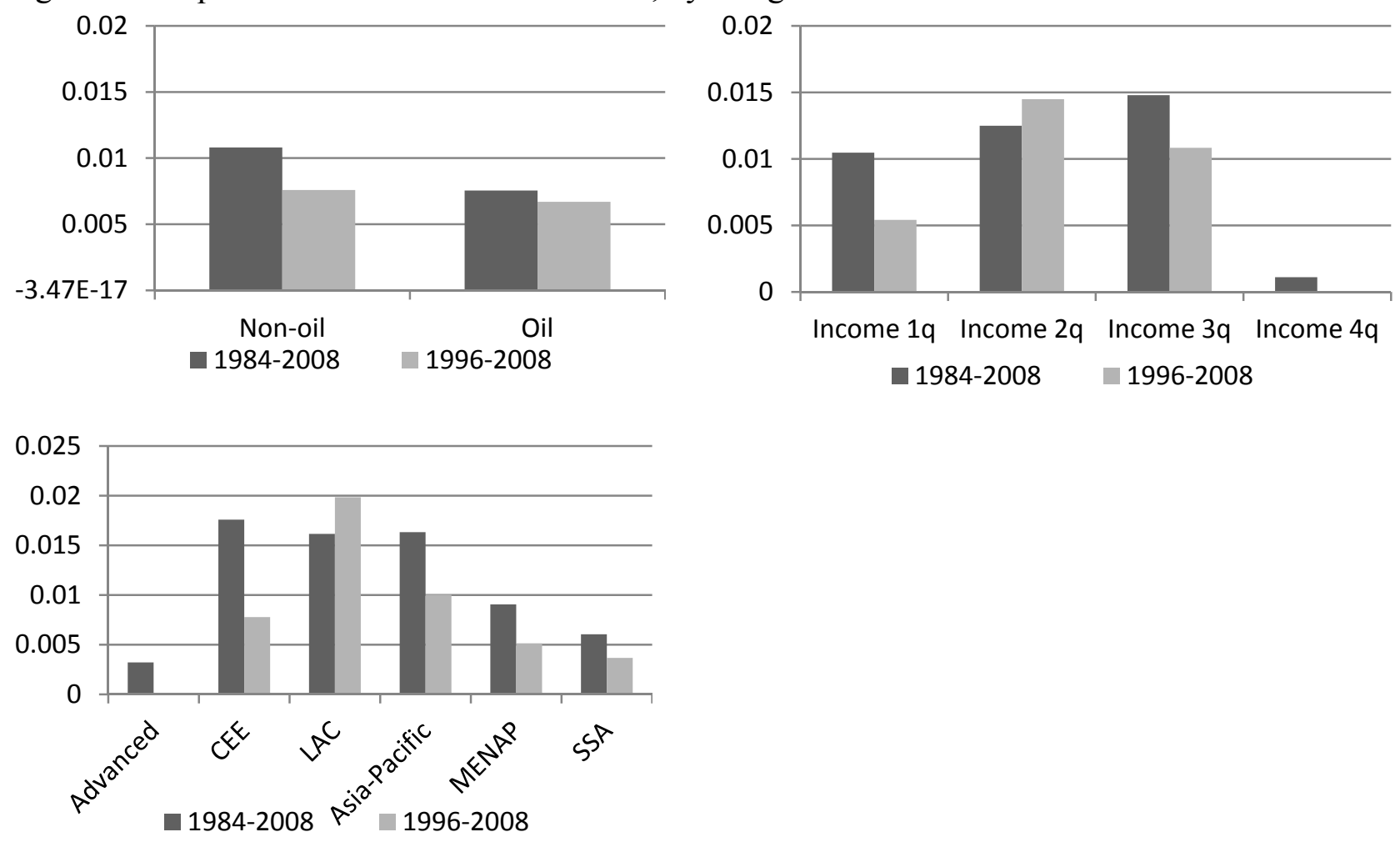

Note: $1 \mathrm{q}$ is the lowest quartile and $4 \mathrm{q}$ is the highest 


\section{ANNEX II: DATA SOURCES}

Variable

GDP per capita

Real GDP growth

Inflation

Openness

Unemployment

Youth Unemployment

Schooling

Infant Mortality

Age dependency (young)

Age dependency (old)

Fertility rate

Pop. growth

Poverty gap

High income share

\section{GINI}

Budget Balance

Debt-ratio

Share of FCD debt

Voice \& Accountability

Political Stability

Government Efficiency

Regulatory Quality

Rule of Law

\section{Control of Corruption}

Internal Accountability

(WGI)*

External Accountability (WGI)*

Democratic Accountability

Internal Conflict

Military in Politics

Bureaucracy Quality

Investment Profile

Law \& Order

Corruption

External Accountability (ICRG)*

Internal Accountability
Definition

Log of GDP per capita in PPP terms, in constant prices 2005

WEO

Annual growth rate of real GDP

WEO

Consumer price inflation

WEO

Log of Exports plus Imports to GDP ratio

WEO

Unemployment rate

WEO

Unemployment rate for those under 25 years of age

WDI

IIASA/VID Projection: Mean years of schooling, age 25+, male

WDI

Mortality rate, infant (per 1,000 live births)

WDI

Age dependency ratio, young (\% of working-age population) $\quad$ WDI

Age dependency ratio, old (\% of working-age population) I WDI

Fertility rate, total (births per woman) $\quad$ WDI

Population growth (annual \%) $\quad$ WDI

Poverty gap at $\$ 1.25$ a day (PPP) (\%) WDI

Income share held by highest $10 \% \quad$ WDI

GINI coefficient $\quad$ WDI

Overall fiscal balance (general government revenues minus general government expenditures) to WEO GDP ratio

Share of public debt denominated in foreign currency (in percent of total public debt)

WEO

Perception of the extent to which a country's citizens are able to participate in selecting their government, as well as freedom of expression, freedom of association, and a free media

Perception of the likelihood that the government will be destabilized or overthrown by unconstitutional or violent means, including domestic violence and terrorism

Perception of the quality of public services, the quality of the civil service and the degree of its independence from political pressures, the quality of policy formulation and implementation, and the credibility of the government's commitment to such policies

Perception of the ability of the government to formulate and implement sound policies and regulations that permit and promote private sector development

Perception of the extent to which agents have confidence in and abide by the rules of society, and in particular the quality of contract enforcement, property rights, the police, and the courts, as well as the likelihood of crime and violence

Perception of the extent to which public power is exercised for private gain, including both petty and grand forms of corruption, as well as "capture" of the state by elites and private interests

First principal component of Voice \& Accountability and Political Stability

WGI

WGI

WGI

WGI

WGI

First principal component of Government Efficiency, Regulatory Quality, and Political Stability, Rule of Law, Control of Corruption

WGI

A measure of how responsive government is to its people

ICRG

Assessment of political violence in the country and its actual or potential impact on governance Assessment of military's involvement in politics, even at a peripheral level, treated as a diminution of democratic accountability

The institutional strength and quality of the bureaucracy, expertise to govern without drastic changes in policy or interruptions in government services

Assessment of factors affecting the risk to investment that are not covered by other political, economic and financial risk components

Assessment of the strength and impartiality of the legal system, and of popular observance of the law Assessment of corruption within the political system

ICRG

First principal component of Democratic Accountability, Military in Politics and Internal Conflict

ICRG

First principal component of Bureaucracy Quality, Investment Profile, Law and Order, and 
(ICRG)*

Type of Regime

Effective Executive (type)

Effective Executive

(selection)

Legislative Effectiveness

Legislative Selection

External Accountability

(CNTS)*

Swap spread

EMBI spread

Bond spread

IMF-financing

Major Government Crises

Purges

Revolutions

Anti-government

Demonstrations
Corruption

4-Civilian, 3-Military Civilian, 2-Military, 1-Other

CNTS

2- President or Premier, 1-Monarch or Military $\quad$ CNTS

2-Direct or Indirect election, 1-Nonelective $\quad$ CNTS

3-Effective, 2-Partially Effective, 1-Ineffective, 0-none $\quad$ CNTS

2-Elective, 1-Nonelective, 0-none $\quad$ CNTS

$\begin{array}{ll}\text { First principal component of all components from CNTS } & \text { CNTS }\end{array}$

Spread between the bond yield and the interest rate on the swap of the same maturity Bloomberg

Emerging Markets Bond Index spread developed by JPMorgan

Bloomberg

Government bond spreads (relative to 10-year US Treasury bond) WEO

IMF program-supported non-concessional financing (in percent of quota) IMF

Any rapidly developing situation that threatens to bring the downfall of the present regime - CNTS

excluding situations of revolt aimed at such overthrow

Any systematic elimination by jailing or execution of political opposition within the ranks of the $\quad$ CNTS

regime or the opposition

Any illegal or forced change in the top government elite, any attempt at such a change, or any

CNTS

successful or unsuccessful armed rebellion whose aim is independence from the central government

Any peaceful public gathering of at least 100 people for the primary purpose of displaying or voicing

their opposition to government policies or authority, excluding demonstrations of a distinctly anti-

CNTS

WDI = World Development Indicators; WEO = World Economic Outlook; WGI = World Governance Indicators; CNTS $=$ Cross-National Time Series data archives. $*=$ IMF staff calculations. 


\section{ANNEX III: Fiscal AND POLITICAL STREsS Events}

Table 1: Fiscal stress events

\begin{tabular}{|c|c|c|}
\hline Country & FSI, years & Default*, years \\
\hline \multirow[t]{2}{*}{ Albania } & $1992-1993$ & 1991-1995 \\
\hline & $1998-2001$ & \\
\hline Argentina & $2002-2005$ & $2001-2005$ \\
\hline Armenia & $2000-2010$ & \\
\hline \multirow[t]{4}{*}{ Bangladesh } & 1980 & \\
\hline & 1986-1987 & \\
\hline & 1990 & \\
\hline & $2003-2007$ & \\
\hline \multirow[t]{2}{*}{ Benin } & 1989-1995 & \\
\hline & 2010 & \\
\hline \multirow[t]{5}{*}{ Bolivia } & $1973-1973$ & \\
\hline & 1980-1981 & 1980-1997 \\
\hline & 1986-1988 & \\
\hline & 1994 & \\
\hline & 1998 & \\
\hline Bosnia \& Herzegovina & 2009-2011 & $1992-1997$ \\
\hline Brazil & 1999-2001 & 1994 \\
\hline \multirow[t]{4}{*}{ Burkina Faso } & 1991-1993 & \\
\hline & 1996 & $1987-1996$ \\
\hline & 1999 & \\
\hline & 2010 & \\
\hline \multirow[t]{3}{*}{ Burundi } & 1986-1988 & \\
\hline & 1991-1994 & \\
\hline & 2004-2007 & \\
\hline \multirow[t]{2}{*}{ Cambodia } & 1994-1997 & \\
\hline & $1999-2003$ & \\
\hline Cameroon & & 1985-1992 \\
\hline Cape Verde & $2002-2005$ & 1981-1996 \\
\hline \multirow[t]{4}{*}{ Central African Rep. } & 1983 & $1981-2006$ \\
\hline & 1987 & \\
\hline & 1998-2002 & \\
\hline & $2006-2010$ & \\
\hline \multirow[t]{3}{*}{ Chad } & 1987-1990 & \\
\hline & 1995 & \\
\hline & $2000-2004$ & \\
\hline Colombia & 2009-2010 & \\
\hline \multirow[t]{2}{*}{ Comoros } & 1991-1994 & \\
\hline & 2009-2011 & \\
\hline \multirow[t]{5}{*}{ Congo Dem. Rep } & 1979-1981 & $1977-2006$ \\
\hline & 1983-1984 & \\
\hline & $1986-1987$ & \\
\hline & $2002-2006$ & \\
\hline & 2009 & \\
\hline Republic of Congo & & $1985-1992$ \\
\hline \multirow[t]{3}{*}{ Costa Rica } & 1980-1982 & 1981-1990 \\
\hline & $1985-1986$ & \\
\hline & 2009-2010 & \\
\hline \multirow[t]{2}{*}{ Djibouti } & 1999 & \\
\hline & $2008-2011$ & \\
\hline \multirow[t]{3}{*}{ Dominica } & $1981-1983$ & $2003-2005$ \\
\hline & 1986-1989 & \\
\hline & $2003-2005$ & \\
\hline
\end{tabular}

\begin{tabular}{|c|c|c|}
\hline Country & FSI, years & Default*, years \\
\hline Dominican Republic & & 2005 \\
\hline \multirow[t]{4}{*}{ Ecuador } & 2000 & 1995 \\
\hline & 2009 & $1999-2000$ \\
\hline & & 2005 \\
\hline & & 2009 \\
\hline \multirow[t]{2}{*}{ Estonia } & 1998 & \\
\hline & $2000-2001$ & \\
\hline Ethiopia & 1993-1997 & 1991-1997 \\
\hline \multirow[t]{2}{*}{ Gambia } & $1982-1988$ & 1986-1990 \\
\hline & $1998-2005$ & \\
\hline Greece & 2010-2011 & \\
\hline \multirow[t]{2}{*}{ Grenada } & 1981-1984 & 2004-2005 \\
\hline & $2006-2010$ & \\
\hline \multirow[t]{2}{*}{ Guatemala } & & 1986 \\
\hline & & 1989 \\
\hline \multirow[t]{2}{*}{ Guinea } & 1987 & 1986-1998 \\
\hline & $1991-2000$ & \\
\hline \multirow[t]{4}{*}{ Guinea-Bissau } & $1987-1990$ & 1983-1996 \\
\hline & 1995-1998 & \\
\hline & $2000-2003$ & \\
\hline & $2010-2011$ & \\
\hline \multirow[t]{3}{*}{ Guyana } & 1979-1980 & 1970 \\
\hline & 1990-1991 & $1982-2006$ \\
\hline & 1994-1998 & \\
\hline \multirow[t]{5}{*}{ Haiti } & 1978 & \\
\hline & $1982-1983$ & \\
\hline & 1986-1988 & \\
\hline & 1996 & \\
\hline & 2006-2010 & \\
\hline \multirow[t]{2}{*}{ Honduras } & 1992 & $1983-2006$ \\
\hline & 1994-2005 & \\
\hline Hungary & $2008-2010$ & \\
\hline Iceland & 2008-2011 & \\
\hline India & 1981-1984 & 1972-1976 \\
\hline Ireland & $2010-2011$ & \\
\hline \multirow[t]{4}{*}{ Jordan } & 1989-1991 & 1989-1993 \\
\hline & 1994 & \\
\hline & 1996 & \\
\hline & 1999 & \\
\hline \multirow[t]{6}{*}{ Kenya } & $1975-1977$ & 1994-1998 \\
\hline & $1979-1980$ & 2000 \\
\hline & $1982-1983$ & \\
\hline & 1988-1989 & \\
\hline & $1994-2000$ & \\
\hline & 2003 & \\
\hline \multirow[t]{4}{*}{ Kyrgyz Republic } & 1994 & \\
\hline & 1998 & \\
\hline & 2001 & \\
\hline & 2008 & \\
\hline \multirow[t]{3}{*}{ Lao People's Dem.Rep } & 1980-1981 & \\
\hline & 1989-1997 & \\
\hline & 2001-2005 & \\
\hline
\end{tabular}




\begin{tabular}{|c|c|c|}
\hline Country & FSI, years & Default*, years \\
\hline Latvia & $2008-2010$ & \\
\hline \multirow[t]{3}{*}{ Lesotho } & $1988-1991$ & \\
\hline & 2001-2004 & \\
\hline & $2010-2011$ & \\
\hline \multirow[t]{2}{*}{ Liberia } & $1980-1983$ & $1981-2006$ \\
\hline & 2008 & \\
\hline \multirow[t]{2}{*}{ Macedonia } & 1997-1999 & 1992-1997 \\
\hline & 2005-2008 & \\
\hline \multirow[t]{4}{*}{ Madagascar } & 1980-1982 & $1981-2002$ \\
\hline & 1987 & \\
\hline & 1989 & \\
\hline & 1996-2005 & \\
\hline \multirow[t]{3}{*}{ Malawi } & 1983 & 1982 \\
\hline & 1988-1989 & 1988 \\
\hline & 1993-1997 & \\
\hline Maldives & 2009-2011 & \\
\hline \multirow[t]{3}{*}{ Mali } & $1982-1983$ & \\
\hline & $1988-1990$ & \\
\hline & 1992-1996 & \\
\hline \multirow{6}{*}{ Mauritania } & 1980-1981 & $1992-1996$ \\
\hline & 1986 & \\
\hline & 1989 & \\
\hline & 1992-1996 & \\
\hline & 1999-2002 & \\
\hline & 2010-2011 & \\
\hline Mexico & 2009-2010 & \\
\hline \multirow[t]{3}{*}{ Moldova } & 1995-1996 & 1998 \\
\hline & 2000 & 2002 \\
\hline & 2006-2011 & \\
\hline \multirow[t]{2}{*}{ Mongolia } & $1991-2000$ & $1997-2000$ \\
\hline & $2009-2010$ & \\
\hline \multirow[t]{2}{*}{ Mozambique } & $1987-1990$ & 1980 \\
\hline & $1996-2010$ & 1983-1992 \\
\hline \multirow[t]{2}{*}{ Myanmar } & 1996-1998 & $1997-2006$ \\
\hline & 2006-2010 & \\
\hline \multirow[t]{3}{*}{ Nepal } & 1986-1987 & \\
\hline & 1992 & \\
\hline & 1994 & \\
\hline \multirow[t]{3}{*}{ Nicaragua } & 1970 & $1979-2006$ \\
\hline & 1979 & \\
\hline & 1994-2002 & \\
\hline \multirow[t]{4}{*}{ Niger } & 1983 & 1983-1991 \\
\hline & 1986 & \\
\hline & 1988 & \\
\hline & 1996-2004 & \\
\hline Nigeria & $1987-1988$ & $1982-2005$ \\
\hline Pakistan & 2009 & \\
\hline Papua New Guinea & 2009-2010 & \\
\hline
\end{tabular}

\begin{tabular}{|c|c|c|}
\hline Country & FSI, years & Default*, years \\
\hline Peru & & 1997 \\
\hline Poland & $2009-2010$ & \\
\hline Portugal & $2010-2011$ & \\
\hline Romania & $2009-2010$ & \\
\hline Russian Federation & 1999 & $1998-2000$ \\
\hline \multirow[t]{4}{*}{ Samoa } & 1984 & \\
\hline & 1986 & \\
\hline & 1992-1999 & \\
\hline & $2002-2006$ & \\
\hline \multirow[t]{4}{*}{ Senegal } & $1980-1983$ & $1981-1985$ \\
\hline & $1985-1988$ & 1990 \\
\hline & 1994 & $1992-1996$ \\
\hline & 1998 & \\
\hline \multirow[t]{3}{*}{ Sierra Leone } & $1981-1987$ & 1983-1984 \\
\hline & 1994-1995 & 1986-1998 \\
\hline & $2001-2005$ & \\
\hline Slovenia & 1991-1994 & 1992-1994 \\
\hline \multirow[t]{3}{*}{ Solomon Islands } & 1993 & 1996-2006 \\
\hline & 1995 & \\
\hline & 1998-1999 & \\
\hline Sudan & $1979-1983$ & $1979-2006$ \\
\hline \multirow[t]{2}{*}{ Tajikistan } & $1998-2006$ & \\
\hline & $2009-2011$ & \\
\hline \multirow[t]{5}{*}{ Tanzania } & $1980-1982$ & 1984-2004 \\
\hline & $1987-1988$ & \\
\hline & 1991-1994 & \\
\hline & $1996-2000$ & \\
\hline & 2009 & \\
\hline \multirow[t]{3}{*}{ Thailand } & 1981 & \\
\hline & $1985-1986$ & \\
\hline & $1997-2000$ & \\
\hline \multirow[t]{4}{*}{ Togo } & $1979-1983$ & $1979-1980$ \\
\hline & $1988-1989$ & $1982-1988$ \\
\hline & 1994-1998 & 1991-1997 \\
\hline & $2008-2011$ & \\
\hline Turkey & 2002 & \\
\hline \multirow[t]{2}{*}{ Uganda } & $1982-1983$ & 1981-1992 \\
\hline & $1985-1992$ & 2000 \\
\hline Ukraine & $2008-2010$ & 2000 \\
\hline Uruguay & & 2003 \\
\hline \multirow[t]{2}{*}{ Venezuela } & & 1995-1998 \\
\hline & & 2004-2005 \\
\hline \multirow[t]{2}{*}{ Yemen } & 1996-1997 & $1985-2001$ \\
\hline & $2010-2011$ & \\
\hline \multirow[t]{3}{*}{ Zambia } & $1976-1984$ & 1983-1994 \\
\hline & 1986 & \\
\hline & $1995-1996$ & \\
\hline Zimbabwe & 1983-1992 & 1970-1980 \\
\hline
\end{tabular}

* These are actual events of sovereign debt default or restructuring as defined by $S \& P$ 
Table 2: Political stress events

\begin{tabular}{|c|c|c|c|c|c|}
\hline Country & PSI, years & Regime change $^{\wedge}$, years & Country & PSI, years & Regime change ${ }^{\wedge}$, years \\
\hline \multirow[t]{2}{*}{ Afghanistan } & 1979 & 2004 & Equatorial Guinea & & 1992 \\
\hline & 1992 & & \multirow[t]{2}{*}{ Ethiopia } & 1974 & \\
\hline Albania & 1997 & 1990 & & 1978 & \\
\hline Algeria & & 1996 & \multirow[t]{2}{*}{ Fiji } & & 1991 \\
\hline \multirow[t]{6}{*}{ Argentina } & 1970 & 1972 & & & 2000 \\
\hline & 1976 & 1982 & Gabon & & 1989 \\
\hline & 1982 & & Gambia & & 1996 \\
\hline & 1989 & & Georgia & 1992 & 2003 \\
\hline & 2001 & & Ghana & & 1978 \\
\hline & 2001 & & & & 1992 \\
\hline \multirow[t]{2}{*}{ Bangladesh } & \multirow[t]{2}{*}{1987} & 1985 & Greece & 1973 & 1973 \\
\hline & & 1987 & \multirow[t]{2}{*}{ Grenada } & & 1983 \\
\hline Benin & & 1990 & & & 2000 \\
\hline Bhutan & & 2006 & \multirow[t]{2}{*}{ Guatemala } & 1970 & 1985 \\
\hline \multirow[t]{4}{*}{ Bolivia } & $1970-1971$ & 1978 & & 1993 & \\
\hline & 1973-1974 & 1981 & \multirow[t]{3}{*}{ Guinea-Bissau } & & 1993 \\
\hline & 2003 & & & & 1999 \\
\hline & 2005 & & & & 2004 \\
\hline Brazil & $1970-1971$ & 1984 & Haiti & & 2006 \\
\hline Bulgaria & 1989 & 1989 & Honduras & & 1970 \\
\hline \multirow[t]{2}{*}{ Burkina Faso } & & 1977 & & & 1981 \\
\hline & & 1991 & Hungary & & 1989 \\
\hline \multirow[t]{2}{*}{ Burundi } & 1993 & 1992 & India & 1993 & \\
\hline & 1996 & 2004 & Indonesia & 1998 & 1998 \\
\hline Burundi & & 2004 & & 2001 & \\
\hline \multirow[t]{2}{*}{ Cambodia } & $1970-1971$ & 1997 & Iran & 1978-1979 & \\
\hline & 1995 & & Iraq & 1991 & \\
\hline Cameroon & & 1991 & & $2005-2006$ & \\
\hline Canada & 1970 & & Ireland & 1970 & \\
\hline Cape Verde & & 1990 & Israel & 1976 & 2002 \\
\hline \multirow{3}{*}{$\begin{array}{l}\text { Central African } \\
\text { Rep. }\end{array}$} & & & Italy & 1970 & \\
\hline & & 1992 & & 1992 & \\
\hline & & 2004 & Jordan & 1970 & \\
\hline Chad & 1979 & 1996 & Kenya & & 1991 \\
\hline Chile & $1971-1973$ & 1989 & Korea & 1974 & 1972 \\
\hline China & 1976 & & & $1979-1980$ & \\
\hline \multirow[t]{2}{*}{ Colombia } & 1970 & & & 1987 & \\
\hline & 2003 & & Kyrgyz Republic & & 1994 \\
\hline \multirow[t]{2}{*}{ Comoros } & 1995 & 1991 & Lebanon & 1970 & \\
\hline & & 2003 & & 1984 & \\
\hline \multirow[t]{2}{*}{ Congo Dem. Rep } & 1992 & 2005 & Lesotho & & 2001 \\
\hline & 1997 & & Liberia & $1980-1981$ & 1984 \\
\hline \multirow[t]{2}{*}{ Republic of Congo } & & 1991 & & & 1996 \\
\hline & & 2002 & & & 2005 \\
\hline Cyprus & & 1982 & Madagascar & & 1992 \\
\hline \multirow[t]{3}{*}{ Czech Republic } & 1970 & 1988 & Malawi & & 1993 \\
\hline & 1972 & & Malaysia & & 1970 \\
\hline & 1989 & & Maldives & & 2007 \\
\hline Ecuador & 2005 & 1978 & Mali & & 1991 \\
\hline & & 2001 & Mauritania & & 1991 \\
\hline Egypt & & 1978 & & & 2006 \\
\hline El Salvador & 1980 & 1976 & Mexico & 1995 & \\
\hline & & 1983 & Moldova & & 1993 \\
\hline
\end{tabular}




\begin{tabular}{|c|c|c|c|c|c|}
\hline Country & PSI, years & Regime change $^{\wedge}$, years & Country & PSI, years & Regime change ${ }^{\wedge}$, years \\
\hline Mongolia & & 1989 & Singapore & & 1983 \\
\hline Mozambique & & 1993 & South Africa & 1985 & \\
\hline Myanmar & 1988 & & \multirow[t]{2}{*}{ Spain } & 1970 & \multirow[t]{2}{*}{1976} \\
\hline \multirow[t]{2}{*}{ Nepal } & 2001 & 1990 & & $1975-1976$ & \\
\hline & & 2007 & \multirow{2}{*}{$\begin{array}{l}\text { St. Vincent \& } \\
\text { Grenadines }\end{array}$} & & \\
\hline \multirow[t]{2}{*}{ Nicaragua } & & 1973 & & & 1993 \\
\hline & & 1983 & \multirow{3}{*}{$\begin{array}{l}\text { Sudan } \\
\text { Suriname }\end{array}$} & 1979 & 1985 \\
\hline \multirow[t]{2}{*}{ Niger } & & 1992 & & & 1987 \\
\hline & & 1999 & & & 1990 \\
\hline \multirow[t]{2}{*}{ Nigeria } & & 1978 & \multirow{2}{*}{$\begin{array}{l}\text { Syrian Arab } \\
\text { Republic }\end{array}$} & 1970 & \\
\hline & & 1998 & & \multirow{2}{*}{1992} & 1994 \\
\hline \multirow[t]{3}{*}{ Pakistan } & 1971 & 1971 & $\begin{array}{l}\text { Tajikistan } \\
\text { Tanzania }\end{array}$ & & 1994 \\
\hline & 1977 & 1987 & \multirow{4}{*}{ Thailand } & \multirow{4}{*}{1976} & 1074 \\
\hline & & 2007 & & & $\begin{array}{l}19 / 4 \\
1078\end{array}$ \\
\hline Panama & & 1989 & & & 1991 \\
\hline \multirow[t]{2}{*}{ Peru } & 2000 & 1979 & & & 2007 \\
\hline & & 2000 & \multirow{2}{*}{\multicolumn{2}{|c|}{ Togo }} & 1993 \\
\hline \multirow[t]{2}{*}{ Philippines } & 1972 & 1980 & & & 1093 \\
\hline & 1986-1987 & & \multicolumn{2}{|l|}{ Tunisia } & 1993 \\
\hline Poland & 1982 & 1988 & \multirow{2}{*}{ Turkey } & 1977 & \multirow{2}{*}{1982} \\
\hline Portugal & 1974-1975 & 1974 & & 1995 & \\
\hline Romania & & 1989 & \multirow[t]{2}{*}{ Uganda } & \multirow[t]{2}{*}{1972} & \multirow{2}{*}{$\begin{array}{l}1979 \\
2005\end{array}$} \\
\hline Russian Federation & 1994 & 1990 & & & \\
\hline Rwanda & & 2002 & United States & \multirow[t]{2}{*}{1970} & \\
\hline Senegal & & 1977 & Uruguay & & 1984 \\
\hline \multirow[t]{3}{*}{ Serbia } & 1972 & 1990 & \multirow[t]{2}{*}{ Venezuela } & \multirow{2}{*}{$\begin{array}{l}1992 \\
2002\end{array}$} & \\
\hline & 1991 & 2005 & & & \\
\hline & 1999 & & Yemen & & 1992 \\
\hline Seychelles & & 1992 & Zambia & & 1990 \\
\hline Sierra Leone & & 1995 & Zimbabwe & & 2007 \\
\hline & & 2001 & & & \\
\hline
\end{tabular}

^ These are actual episodes of regime change based on the 'Democracy Dictatorship" database from Cheibub el al, 2009. 
ANNEX IV: GROUPING OF COUNTRIES BY REGION AND HYDROCARBON EXPORT

\begin{tabular}{|c|c|c|c|c|c|c|}
\hline & Asia-Pacific & CCE & LAC & MENAP & SSA & Advanced* \\
\hline $\begin{array}{l}\text { Not } \\
\text { hydrocarbon } \\
\text { exporting } \\
\text { countries }\end{array}$ & $\begin{array}{l}\text { Bangladesh } \\
\text { Bhutan } \\
\text { Cambodia } \\
\text { China } \\
\text { Fiji } \\
\text { Hong Kong } \\
\text { India } \\
\text { Indonesia } \\
\text { Kiribati } \\
\text { Laos } \\
\text { Malaysia } \\
\text { Maldives } \\
\text { Mongolia } \\
\text { Myanmar } \\
\text { Nepal } \\
\text { P.N.G. } \\
\text { Philippines } \\
\text { Samoa } \\
\text { Singapore } \\
\text { Solomon Is. } \\
\text { Sri Lanka } \\
\text { Taiwan } \\
\text { Thailand } \\
\text { Tonga } \\
\text { Vanuatu } \\
\text { Vietnam }\end{array}$ & $\begin{array}{l}\text { Albania } \\
\text { Armenia } \\
\text { Belarus } \\
\text { Bosnia-H. } \\
\text { Bulgaria } \\
\text { Croatia } \\
\text { Czech Rep. } \\
\text { Estonia } \\
\text { Georgia } \\
\text { Hungary } \\
\text { Kosovo } \\
\text { Latvia } \\
\text { Lithuania } \\
\text { Macedonia } \\
\text { Moldova } \\
\text { Montenegro } \\
\text { Poland } \\
\text { Romania } \\
\text { Serbia } \\
\text { Slovakia } \\
\text { Slovenia } \\
\text { Turkey } \\
\text { Ukraine }\end{array}$ & $\begin{array}{l}\text { Antigua } \\
\text { Argentina } \\
\text { Bahamas } \\
\text { Barbados } \\
\text { Belize } \\
\text { Bolivia } \\
\text { Brazil } \\
\text { Chile } \\
\text { Colombia } \\
\text { Costa Rica } \\
\text { Dom. Rep. } \\
\text { Dominica } \\
\text { Ecuador^ } \\
\text { El Salvador } \\
\text { Grenada } \\
\text { Guatemala } \\
\text { Guyana } \\
\text { Haiti } \\
\text { Honduras } \\
\text { Jamaica } \\
\text { Mexico } \\
\text { Nicaragua } \\
\text { Panama } \\
\text { Paraguay } \\
\text { Peru } \\
\text { St. Kitts \& N. } \\
\text { St. Lucia } \\
\text { St. Vincent } \\
\text { Suriname } \\
\text { Uruguay } \\
\text { Venezuela^ }\end{array}$ & $\begin{array}{l}\text { Afghanistan } \\
\text { Djibouti } \\
\text { Egypt } \\
\text { Jordan } \\
\text { Kyrgyzstan } \\
\text { Lebanon } \\
\text { Mauritania } \\
\text { Morocco } \\
\text { Pakistan } \\
\text { Syria } \\
\text { Tajikistan } \\
\text { Tunisia } \\
\text { Uzbekistan }\end{array}$ & $\begin{array}{l}\text { Benin } \\
\text { Botswana } \\
\text { Burkina Faso } \\
\text { Burundi } \\
\text { Cape Verde } \\
\text { C.A.R. } \\
\text { Comoros } \\
\text { Congo, D.R. } \\
\text { Cote d'Ivoire } \\
\text { Eritrea } \\
\text { Ethiopia } \\
\text { Gambia } \\
\text { Ghana } \\
\text { Guinea } \\
\text { Guinea-Bissau } \\
\text { Kenya } \\
\text { Lesotho } \\
\text { Liberia } \\
\text { Madagascar } \\
\text { Malawi } \\
\text { Mali } \\
\text { Mauritius } \\
\text { Mozambique } \\
\text { Namibia } \\
\text { Niger } \\
\text { Rwanda } \\
\text { Sao Tome P. } \\
\text { Senegal } \\
\text { Seychelles } \\
\text { Sierra Leone } \\
\text { South Africa } \\
\text { Swaziland } \\
\text { Tanzania } \\
\text { Togo } \\
\text { Uganda } \\
\text { Zambia } \\
\text { Zimbabwe }\end{array}$ & $\begin{array}{l}\text { Australia } \\
\text { Austria } \\
\text { Belgium } \\
\text { Canada } \\
\text { Cyprus } \\
\text { Denmark } \\
\text { Finland } \\
\text { France } \\
\text { Germany } \\
\text { Greece } \\
\text { Iceland } \\
\text { Ireland } \\
\text { Israel } \\
\text { Italy } \\
\text { Japan } \\
\text { Korea, South } \\
\text { Luxembourg } \\
\text { Malta } \\
\text { Netherlands } \\
\text { New Zealand } \\
\text { Norway^ } \\
\text { Portugal } \\
\text { Spain } \\
\text { Sweden } \\
\text { Switzerland } \\
\text { United Kingdom } \\
\text { United States }\end{array}$ \\
\hline
\end{tabular}




\begin{tabular}{|l|l|l|l|l|l|l|}
\hline & Asia-Pacific & CCE & LAC & MENAP & \multicolumn{1}{|c|}{ SSA } & Advanced* \\
\hline & & & & Algeria & Angola & \\
& & & Azerbaijan & Cameroon & \\
& & & Bahrain & Chad \\
& & & Congo-Brazza. & \\
Hydrocarbon \\
exporting \\
countries
\end{tabular}

$\mathrm{CCE}=\mathrm{Central}$ and Eastern Europe; LAC = Latin-America and the Caribbean; MENAP = Middle-East, North Africa and Pakistan; SSA = Sub-Saharan Africa. * All the advanced countries were aggregated in a single group. ${ }^{\wedge}$ Ecuador and Venezuela are hydrocarbon-exporting countries, but cannot be placed in a separate group (LAC oil exporters) with only two elements, so instead of dropping them, they were lumped together with the other Latin-American countries. By the same logic we keep oil-

exporter Norway with all advanced countries. Similarly, we also exclude Russia, which, as the only oil exporter among CEE countries, cannot be matched. The results did not differ in any meaningful way when these three countries were dropped, or when Russia was included. 


\section{ANNEX V: ESTIMATION RESULTS}

Table 1: Difference of means between countries that have fiscal stress events and those that have not

\begin{tabular}{|c|c|c|c|c|c|c|c|c|c|c|c|c|c|c|c|}
\hline & \multicolumn{3}{|c|}{ I } & \multicolumn{3}{|c|}{ II } & \multicolumn{3}{|c|}{ III } & \multicolumn{3}{|c|}{ IV } & \multicolumn{3}{|c|}{$\mathrm{V}$} \\
\hline & D & t-stat & & D & t-stat & & D & t-stat & & D & t-stat & & D & t-stat & \\
\hline Voice \& Accountability & -0.50 & -7.70 & $* * *$ & -0.19 & -3.54 & $* * *$ & -0.17 & -2.99 & $* * *$ & -0.01 & -0.19 & & -0.02 & -0.36 & \\
\hline Political Stability & -0.43 & -6.47 & $* * *$ & -0.19 & -3.07 & $* * *$ & -0.16 & -2.48 & $* *$ & 0.00 & 0.00 & & -0.02 & -0.37 & \\
\hline Government Effectiveness & -0.77 & -11.19 & $* * *$ & -0.31 & -5.95 & $* * *$ & -0.31 & -5.78 & $* * *$ & -0.09 & -1.81 & $*$ & -0.11 & -2.15 & $* *$ \\
\hline Regulatory Quality & -0.60 & -9.20 & $* * *$ & -0.22 & -3.97 & $* * *$ & -0.21 & -3.70 & $* * *$ & -0.01 & -0.11 & & -0.03 & -0.42 & \\
\hline Rule of Law & -0.68 & -10.06 & $* * *$ & -0.26 & -5.09 & $* * *$ & -0.25 & -4.72 & $* * *$ & -0.05 & -1.11 & & -0.07 & -1.30 & \\
\hline Control of Corruption & -0.72 & -10.41 & $* * *$ & -0.29 & -5.82 & $* * *$ & -0.27 & -5.38 & $* * *$ & -0.08 & -1.84 & $*$ & -0.08 & -1.57 & $\wedge$ \\
\hline External Accountability (WGI) & -0.50 & -7.48 & $* * *$ & -0.20 & -3.47 & $* * *$ & -0.17 & -2.82 & $* * *$ & 0.00 & -0.05 & & -0.02 & -0.37 & \\
\hline Internal Accountability (WGI) & -0.72 & -10.58 & $* * *$ & -0.28 & -5.49 & $* * *$ & -0.27 & -5.19 & $* * *$ & -0.06 & -1.27 & & -0.08 & -1.41 & \\
\hline Democratic Accountability & -0.58 & -9.25 & $* * *$ & -0.21 & -3.77 & $* * *$ & -0.13 & -2.15 & $* *$ & -0.17 & -3.11 & $* * *$ & -0.07 & -1.09 & \\
\hline Internal Conflict & -0.40 & -6.86 & $* * *$ & -0.12 & -2.20 & $* *$ & -0.06 & -0.89 & & -0.02 & -0.30 & & 0.09 & 1.35 & \\
\hline Military in Politics & -0.65 & -10.49 & $* * *$ & -0.25 & -4.48 & $* * *$ & -0.21 & -3.36 & $* * *$ & -0.15 & -2.59 & $* * *$ & -0.05 & -0.79 & \\
\hline Bureaucracy Quality & -0.85 & -13.28 & $* * *$ & -0.31 & -5.87 & $* * *$ & -0.31 & -5.47 & $* * *$ & -0.13 & -2.66 & $* * *$ & -0.09 & -1.55 & $\wedge$ \\
\hline Investment Profile & -0.67 & -10.83 & $* * *$ & -0.37 & -6.57 & $* * *$ & -0.26 & -4.08 & $* * *$ & -0.21 & -4.00 & $* * *$ & -0.10 & -1.59 & $\wedge$ \\
\hline Law \& Order & -0.62 & -10.04 & $* * *$ & -0.15 & -3.07 & $* * *$ & -0.15 & -2.70 & $* * *$ & -0.07 & -1.32 & & -0.01 & -0.13 & \\
\hline Corruption & -0.42 & -6.48 & $* * *$ & -0.01 & -0.11 & & -0.02 & -0.29 & & 0.05 & 0.96 & & 0.06 & 0.94 & \\
\hline External Accountability (ICRG) & -0.65 & -10.30 & $* * *$ & -0.23 & -4.17 & $* * *$ & -0.16 & -2.56 & $* *$ & -0.13 & -2.34 & $* *$ & -0.01 & -0.20 & \\
\hline Internal Accountability (ICRG) & -0.80 & -12.41 & $* * *$ & -0.26 & -5.23 & $* * *$ & -0.23 & -4.13 & $* * *$ & -0.11 & -2.38 & $* *$ & -0.04 & -0.77 & \\
\hline External Accountability (CNTS) & -0.05 & -1.05 & & 0.07 & 1.42 & & 0.02 & 0.33 & & 0.11 & 2.07 & $* *$ & 0.10 & 1.61 & $\wedge$ \\
\hline GDP per capita & -0.94 & -15.20 & $* * *$ & -0.32 & -6.08 & $* * *$ & -0.38 & -6.85 & $* * *$ & -0.04 & -0.95 & & -0.05 & -0.87 & \\
\hline Real GDP growth & -0.39 & -1.65 & $*$ & -0.30 & -1.20 & & 0.11 & 0.41 & & -0.17 & -0.67 & & -0.10 & -0.32 & \\
\hline Inflation & 4.49 & 3.92 & $* * *$ & 3.44 & 3.02 & $* * *$ & 1.69 & 1.22 & & 1.02 & 0.75 & & 1.67 & 1.21 & \\
\hline Openness & -0.19 & -5.82 & $* * *$ & -0.16 & -4.85 & $* * *$ & -0.15 & -4.32 & $* * *$ & -0.07 & -2.10 & $* *$ & -0.01 & -0.30 & \\
\hline Budget Balance & -0.02 & -4.84 & $* * *$ & -0.01 & -3.50 & $* * *$ & -0.01 & -2.43 & $* *$ & -0.01 & -3.04 & $* * *$ & -0.01 & -2.48 & $* *$ \\
\hline Debt-to-GDP & 0.24 & 7.07 & $* * *$ & 0.22 & 6.13 & $* * *$ & 0.22 & 5.71 & $* * *$ & 0.18 & 4.68 & $* * *$ & 0.18 & 4.10 & $* * *$ \\
\hline Share of FCD debt & 0.13 & 5.17 & $* * *$ & 0.15 & 5.42 & $* * *$ & 0.16 & 6.34 & $* * *$ & 0.09 & 3.44 & $* * *$ & 0.11 & 4.11 & $* * *$ \\
\hline Age dependency (old) & -2.65 & -9.25 & $* * *$ & -0.39 & -1.97 & $* *$ & -0.52 & -2.40 & $* *$ & -0.14 & -0.69 & & -0.11 & -0.47 & \\
\hline Fertility rate & 0.66 & 6.71 & $* * *$ & -0.02 & -0.27 & & 0.15 & 1.65 & * & -0.15 & -1.72 & $*$ & -0.02 & -0.20 & \\
\hline
\end{tabular}

Note: $\mathrm{D}$ stands for difference of means, t-stat is a t-statistic of the significance test, and stars denote the level of significance: $* * * p<0.01, * * \mathrm{p}<0.05,{ }^{*} \mathrm{p}<0.1, \wedge \mathrm{p}<0.15$. In column I we present simple comparison of means without grouping; in column II - grouping by region and oil dummy; in column III - grouping by region, oil dummy, and year; in column IV, grouping by region, oil dummy, and income; in column V, grouping by region, oil dummy, income, and year. Definitions of the variables and their sources are in Annex II. All variables are measured at time $t-1$, while FSI is at time $t$. 
Table 2: Difference of means between countries that have political stress events and those that have not

\begin{tabular}{|c|c|c|c|c|c|c|c|c|c|c|c|c|c|c|c|}
\hline & \multicolumn{3}{|c|}{$\mathrm{I}$} & \multicolumn{3}{|c|}{ II } & \multicolumn{3}{|c|}{ III } & \multicolumn{3}{|c|}{ IV } & \multicolumn{3}{|c|}{$\mathrm{V}$} \\
\hline & $\mathrm{D}$ & t-stat & & $\mathrm{D}$ & t-stat & & $\mathrm{D}$ & t-stat & & $\mathrm{D}$ & t-stat & & $\mathrm{D}$ & t-stat & \\
\hline Voice \& Accountability & -0.57 & -2.33 & $* *$ & -0.70 & -3.10 & $* * *$ & -0.63 & -3.03 & $* * *$ & -0.58 & -2.63 & $* * *$ & -0.51 & -2.21 & $* *$ \\
\hline Political Stability & -1.48 & -6.10 & $* * *$ & -1.55 & -7.01 & $* * *$ & -1.52 & -7.24 & $* * *$ & -1.37 & -6.24 & $* * *$ & -1.36 & -6.07 & $* * *$ \\
\hline Government Effectiveness & -0.77 & -3.07 & $* * *$ & -0.85 & -3.74 & $* * *$ & -0.66 & -3.61 & $* * *$ & -0.67 & -3.28 & $* * *$ & -0.45 & -2.63 & $* * *$ \\
\hline Regulatory Quality & -0.67 & -2.76 & $* * *$ & -0.77 & -3.53 & $* * *$ & -0.63 & -3.21 & $* * *$ & -0.60 & -2.83 & $* * *$ & -0.41 & -1.90 & $*$ \\
\hline Rule of Law & -0.95 & -3.92 & $* * *$ & -1.02 & -4.60 & $* * *$ & -0.84 & -4.37 & $* * *$ & -0.82 & -4.01 & $* * *$ & -0.61 & -3.29 & $* * *$ \\
\hline Control of Corruption & -0.86 & -3.43 & $* * *$ & -0.92 & -3.96 & $* * *$ & -0.76 & -3.83 & $* * *$ & -0.74 & -3.56 & $* * *$ & -0.53 & -2.80 & $* * *$ \\
\hline External Accountability (WGI) & -1.11 & -4.51 & $* * *$ & -1.21 & -5.40 & $* * *$ & -1.15 & -5.67 & $* * *$ & -1.05 & -4.74 & $* * *$ & -1.00 & -4.51 & $* * *$ \\
\hline Internal Accountability (WGI) & -0.84 & -3.35 & $* * *$ & -0.92 & -4.03 & $* * *$ & -0.74 & -3.88 & $* * *$ & -0.73 & -3.49 & $* * *$ & -0.51 & -2.77 & $* * *$ \\
\hline Democratic Accountability & -0.18 & -1.05 & & -0.28 & -1.79 & $*$ & -0.05 & -0.36 & & -0.20 & -1.34 & & -0.13 & -0.74 & \\
\hline Internal Conflict & -0.94 & -5.23 & $* * *$ & -1.00 & -6.00 & $* * *$ & -0.89 & -5.02 & $* * *$ & -0.84 & -4.94 & $* * *$ & -0.80 & -3.82 & $* * *$ \\
\hline Military in Politics & -0.71 & -4.04 & $* * *$ & -0.78 & -4.92 & $* * *$ & -0.69 & -4.22 & $* * *$ & -0.62 & -4.02 & $* * *$ & -0.51 & -2.70 & $* * *$ \\
\hline Bureaucracy Quality & -0.38 & -2.18 & $* *$ & -0.41 & -2.60 & $* * *$ & -0.21 & -1.36 & & -0.30 & -1.99 & $*$ & -0.11 & -0.65 & \\
\hline Investment Profile & -0.75 & -4.40 & $* * *$ & -0.77 & -4.80 & $* * *$ & -0.46 & -2.94 & $* * *$ & -0.63 & -4.16 & $* * *$ & -0.42 & -2.42 & $* *$ \\
\hline Law \& Order & -0.75 & -4.30 & $* * *$ & -0.78 & -4.79 & $* * *$ & -0.55 & -3.38 & $* * *$ & -0.59 & -3.80 & $* * *$ & -0.44 & -2.27 & $* *$ \\
\hline Corruption & -0.55 & -3.10 & $* * *$ & -0.57 & -3.49 & $* * *$ & -0.52 & -3.23 & $* * *$ & -0.47 & -3.12 & $* * *$ & -0.44 & -2.34 & $* *$ \\
\hline External Accountability (ICRG) & -0.73 & -4.14 & $* * *$ & -0.83 & -5.08 & $* * *$ & -0.66 & -4.11 & $* * *$ & -0.67 & -4.17 & $* * *$ & -0.58 & -3.07 & $* * *$ \\
\hline Internal Accountability (ICRG) & -0.73 & -4.20 & $* * *$ & -0.77 & -4.75 & $* * *$ & -0.53 & -3.52 & $* * *$ & -0.60 & -4.01 & $* * *$ & -0.41 & -2.58 & $* *$ \\
\hline External Accountability (CNTS) & -0.53 & -4.99 & $* * *$ & -0.62 & -6.51 & $* * *$ & -0.57 & -4.76 & $* * *$ & -0.62 & -6.35 & $* * *$ & -0.63 & -4.19 & $* * *$ \\
\hline GDP per capita & -0.18 & -1.25 & & -0.34 & -2.85 & $* * *$ & -0.24 & -1.75 & * & -0.20 & -1.85 & * & -0.11 & -0.77 & \\
\hline Real GDP growth & -3.62 & -5.32 & $* * *$ & -3.59 & -5.90 & $* * *$ & -3.24 & -4.34 & $* * *$ & -3.80 & -5.94 & $* * *$ & -3.24 & -3.19 & $* * *$ \\
\hline Inflation & 10.71 & 2.66 & $* * *$ & 9.91 & 2.45 & $* *$ & 8.14 & 2.04 & $* *$ & 8.29 & 2.01 & $* *$ & 10.28 & 2.51 & $* *$ \\
\hline Openness & -0.59 & -7.30 & $* * *$ & -0.60 & -8.00 & $* * *$ & -0.49 & -5.39 & $* * *$ & -0.52 & -6.83 & $* * *$ & -0.49 & -4.50 & $* * *$ \\
\hline Unemployment & -0.58 & -0.63 & & -0.75 & -0.83 & & 0.69 & 0.74 & & -0.82 & -0.96 & & -0.11 & -0.09 & \\
\hline Youth Unemployment & 0.57 & 0.25 & & 0.21 & 0.09 & & 0.91 & 0.43 & & 0.12 & 0.06 & & 1.78 & 0.68 & \\
\hline Schooling & -0.89 & -2.43 & $* *$ & -1.22 & -3.71 & $* * *$ & -0.46 & -1.16 & & -1.00 & -3.20 & $* * *$ & -0.44 & -0.99 & \\
\hline Infant Mortality & 11.76 & 1.68 & * & 17.70 & 3.01 & $* * *$ & 4.30 & 0.47 & & 12.69 & 2.07 & $* *$ & 6.61 & 0.66 & \\
\hline Age dependency (Young) & 3.46 & 1.40 & & 6.99 & 3.10 & $* * *$ & 1.90 & 0.72 & & 5.10 & 2.34 & $* *$ & 0.47 & 0.14 & \\
\hline Population growth & 0.04 & 0.21 & & 0.25 & 1.64 & $\wedge$ & 0.09 & 0.39 & & 0.33 & 2.38 & $* *$ & 0.11 & 0.50 & \\
\hline Poverty gap & -0.64 & -0.27 & & 2.50 & 1.32 & & 1.46 & 0.65 & & 2.41 & 1.30 & & 0.54 & 0.20 & \\
\hline High income share & 1.45 & 1.00 & & 1.50 & 1.01 & & 0.99 & 0.58 & & 0.90 & 0.64 & & 0.92 & 0.48 & \\
\hline GINI & 1.87 & 0.98 & & 1.84 & 0.93 & & 1.44 & 0.64 & & 0.98 & 0.52 & & 1.40 & 0.54 & \\
\hline
\end{tabular}

Note: $\mathrm{D}$ stands for difference of means, $\mathrm{t}-\mathrm{stat}$ is a t-statistic of the significance test, and stars denote the level of significance: ${ }^{* * *} \mathrm{p}<0.01,{ }^{* *} \mathrm{p}<0.05,{ }^{*} \mathrm{p}<0.1, \wedge \mathrm{p}<0.15$. In column I we present simple comparison of means without grouping; in column II, grouping by region and oil dummy; in column III,- grouping by region, oil dummy and year; in column IV, grouping by region, oil dummy, and income; in column V, grouping by region, oil dummy, income, and year. Definitions of the variables and their sources are in Annex II. All variables are measured at time $t-1$, while PSI is at time $t$. 
Table 3: Logit estimation, Fiscal Stress Indicator is dependent variable

\begin{tabular}{|c|c|c|c|c|c|c|c|c|}
\hline & I & II & III & IV & $\mathrm{V}$ & VI & VII & VIII \\
\hline Government Effectiveness & & $\begin{array}{c}-0.28 * * * \\
(0.09)\end{array}$ & & & & & & \\
\hline Control of Corruption & & & $\begin{array}{c}-0.19 * * \\
(0.08)\end{array}$ & & & & & \\
\hline External Accountability (WGI) & & & & $\begin{array}{l}-0.06 \\
(0.08)\end{array}$ & & & & \\
\hline Internal Accountability (WGI) & & & & & $\begin{array}{l}-0.17^{*} \\
(0.09)\end{array}$ & & & \\
\hline External Accountability (ICRG) & & & & & & $\begin{array}{c}-0.26^{* *} \\
(0.11)\end{array}$ & & \\
\hline Internal Accountability (ICRG) & & & & & & & $\begin{array}{l}-0.20 * \\
(0.11)\end{array}$ & \\
\hline External Accountability (CNTS) & & & & & & & & $\begin{array}{c}0.10 \\
(0.14)\end{array}$ \\
\hline Budget Balance & $\begin{array}{c}0.42^{* * *} \\
(0.16)\end{array}$ & $\begin{array}{c}0.26 \\
(0.17)\end{array}$ & $\begin{array}{l}0.34 * * \\
(0.17)\end{array}$ & $\begin{array}{l}0.36^{* *} \\
(0.17)\end{array}$ & $\begin{array}{l}0.32 * \\
(0.18)\end{array}$ & $\begin{array}{c}0.27 \\
(0.18)\end{array}$ & $\begin{array}{l}0.31^{*} \\
(0.18)\end{array}$ & $\begin{array}{c}0.74 * * * \\
(0.27)\end{array}$ \\
\hline Debt-to-GDP & $\begin{array}{c}-3.70^{* *} \\
(1.82)\end{array}$ & $\begin{array}{l}-3.67 * \\
(2.23)\end{array}$ & $\begin{array}{l}-3.66^{*} \\
(2.14)\end{array}$ & $\begin{array}{l}-3.73 * \\
(2.19)\end{array}$ & $\begin{array}{l}-3.52 \\
(2.14)\end{array}$ & $\begin{array}{c}-8.57 * * \\
(3.38)\end{array}$ & $\begin{array}{c}-8.04 * * \\
(3.44)\end{array}$ & $\begin{array}{l}-3.57 \\
(2.48)\end{array}$ \\
\hline Observations & 842 & 729 & 729 & 733 & 729 & 603 & 603 & 483 \\
\hline pseudo $\log \mathrm{L}$ & -427.74 & -356.84 & -358.11 & -360.81 & -358.30 & -275.61 & -277.01 & -251.65 \\
\hline pseudo R2 & 0.021 & 0.024 & 0.021 & 0.020 & 0.020 & 0.038 & 0.033 & 0.040 \\
\hline
\end{tabular}


Table 4: Logit estimation, Political Stress Indicator is dependent variables

\begin{tabular}{|c|c|c|c|c|c|c|c|c|c|c|c|c|}
\hline & $\mathrm{I}$ & II & III & IV & $\mathrm{V}$ & VI & VII & VIII & IX & $\mathrm{X}$ & $\mathrm{XI}$ & XII \\
\hline Voice \& Accountability & & $\begin{array}{c}-0.87^{* * *} \\
(0.28)\end{array}$ & & & & & & & & & & \\
\hline Political Stability & & & $\begin{array}{c}-1.93 * * * \\
(0.39)\end{array}$ & & & & & & & & & \\
\hline Government Effectiveness & & & & $\begin{array}{c}-1.54 * * * \\
(0.58)\end{array}$ & & & & & & & & \\
\hline Regulatory Quality & & & & & $\begin{array}{l}-0.84 * \\
(0.46)\end{array}$ & & & & & & & \\
\hline Rule of Law & & & & & & $\begin{array}{c}-1.99 * * * \\
(0.60)\end{array}$ & & & & & & \\
\hline Control of Corruption & & & & & & & $\begin{array}{c}-1.42 * * \\
(0.67)\end{array}$ & & & & & \\
\hline External Accountability (WGI) & & & & & & & & $\begin{array}{c}-1.85 * * * \\
(0.40)\end{array}$ & & & & \\
\hline Internal Accountability (WGI) & & & & & & & & & $\begin{array}{c}-1.61 * * * \\
(0.60)\end{array}$ & & & \\
\hline External Accountability (ICRG) & & & & & & & & & & $\begin{array}{c}-0.62^{* *} \\
(0.24)\end{array}$ & & \\
\hline Internal Accountability (ICRG) & & & & & & & & & & & $\begin{array}{c}-0.50^{*} \\
(0.30)\end{array}$ & \\
\hline External Accountability (CNTS) & & & & & & & & & & & & $\begin{array}{c}-0.52 * * * \\
(0.16)\end{array}$ \\
\hline Real GDP growth & $\begin{array}{c}-0.12 * * * \\
(0.02)\end{array}$ & $\begin{array}{c}-0.18^{* * *} \\
(0.05)\end{array}$ & $\begin{array}{c}-0.15^{* *} \\
(0.07)\end{array}$ & $\begin{array}{c}-0.15^{* * *} \\
(0.05)\end{array}$ & $\begin{array}{c}-0.17 * * * \\
(0.04)\end{array}$ & $\begin{array}{c}-0.18^{* * *} \\
(0.05)\end{array}$ & $\begin{array}{c}-0.15 * * * \\
(0.05)\end{array}$ & $\begin{array}{c}-0.17^{* *} \\
(0.07)\end{array}$ & $\begin{array}{c}-0.16^{* * *} \\
(0.05)\end{array}$ & $\begin{array}{c}-0.13^{* * *} \\
(0.04)\end{array}$ & $\begin{array}{c}-0.14 * * * \\
(0.04)\end{array}$ & $\begin{array}{c}-0.12 * * * \\
(0.02)\end{array}$ \\
\hline Inflation & $\begin{array}{l}0.00 * * \\
(0.00)\end{array}$ & $\begin{array}{c}0.00 \\
(0.01)\end{array}$ & $\begin{array}{l}-0.01 \\
(0.01)\end{array}$ & $\begin{array}{l}-0.00 \\
(0.01)\end{array}$ & $\begin{array}{l}-0.00 \\
(0.01)\end{array}$ & $\begin{array}{l}-0.01 \\
(0.01)\end{array}$ & $\begin{array}{l}-0.00 \\
(0.01)\end{array}$ & $\begin{array}{l}-0.01 \\
(0.01)\end{array}$ & $\begin{array}{l}-0.01 \\
(0.01)\end{array}$ & $\begin{array}{c}0.00 \\
(0.00)\end{array}$ & $\begin{array}{l}0.00^{*} \\
(0.00)\end{array}$ & $\begin{array}{c}0.01 * * \\
(0.00)\end{array}$ \\
\hline Openness & $\begin{array}{c}0.01 \\
(0.24)\end{array}$ & $\begin{array}{l}-0.17 \\
(0.27)\end{array}$ & $\begin{array}{l}-0.02 \\
(0.32)\end{array}$ & $\begin{array}{l}-0.13 \\
(0.35)\end{array}$ & $\begin{array}{l}-0.20 \\
(0.33)\end{array}$ & $\begin{array}{l}-0.16 \\
(0.31)\end{array}$ & $\begin{array}{l}-0.18 \\
(0.37)\end{array}$ & $\begin{array}{c}0.05 \\
(0.30)\end{array}$ & $\begin{array}{l}-0.06 \\
(0.36)\end{array}$ & $\begin{array}{l}0.50 * \\
(0.27)\end{array}$ & $\begin{array}{c}0.37 \\
(0.28)\end{array}$ & $\begin{array}{c}0.12 \\
(0.19)\end{array}$ \\
\hline Observations & 631 & 197 & 193 & 183 & 191 & 195 & 183 & 193 & 183 & 303 & 303 & 617 \\
\hline pseudo LogL & -159.71 & -45.84 & -35.88 & -42.95 & -45.96 & -42.36 & -43.50 & -39.55 & -42.64 & -83.62 & -85.22 & -144.29 \\
\hline pseudo R2 & 0.165 & 0.262 & 0.420 & 0.271 & 0.257 & 0.317 & 0.262 & 0.360 & 0.276 & 0.175 & 0.160 & 0.195 \\
\hline
\end{tabular}




\section{ANNEX VI: Predicted Values from Stress Event Models}

Figure 1: Distribution of probability of experiencing a fiscal stress event in Asia-Pacific countries
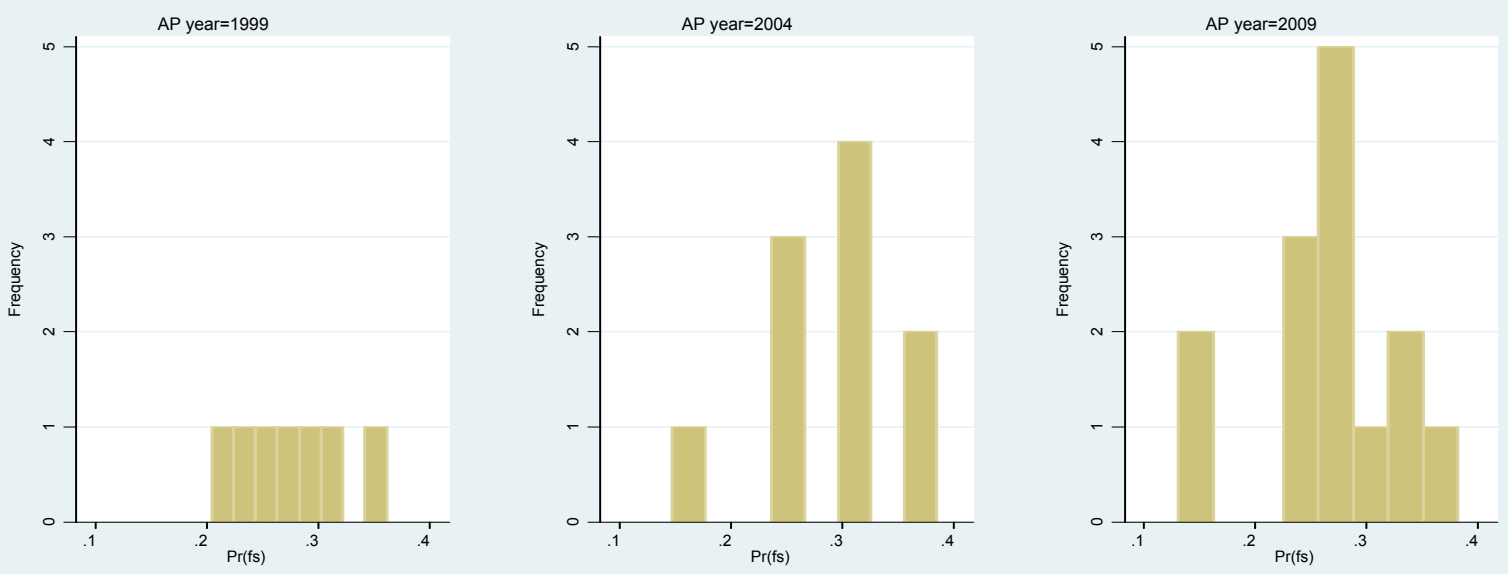

Figure 2: Distribution of probability of experiencing a fiscal stress event in CEE countries
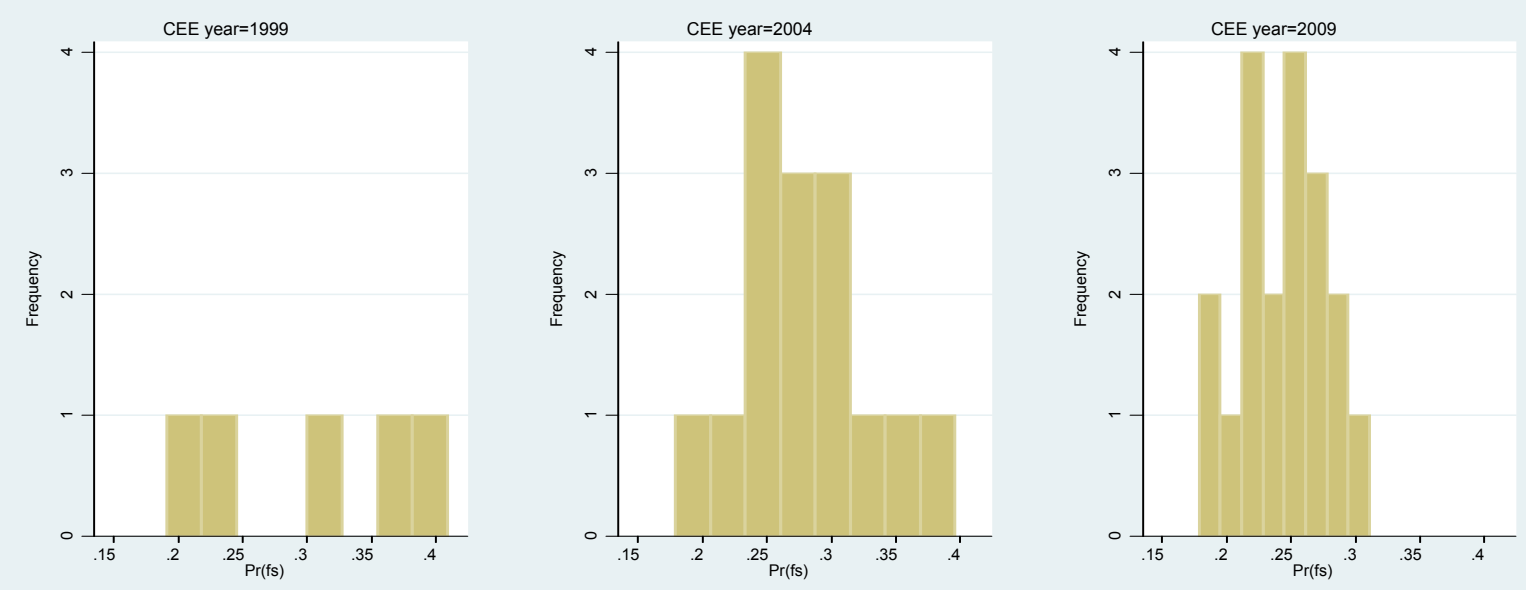

Figure 3: Distribution of probability of experiencing a fiscal stress event in LAC countries
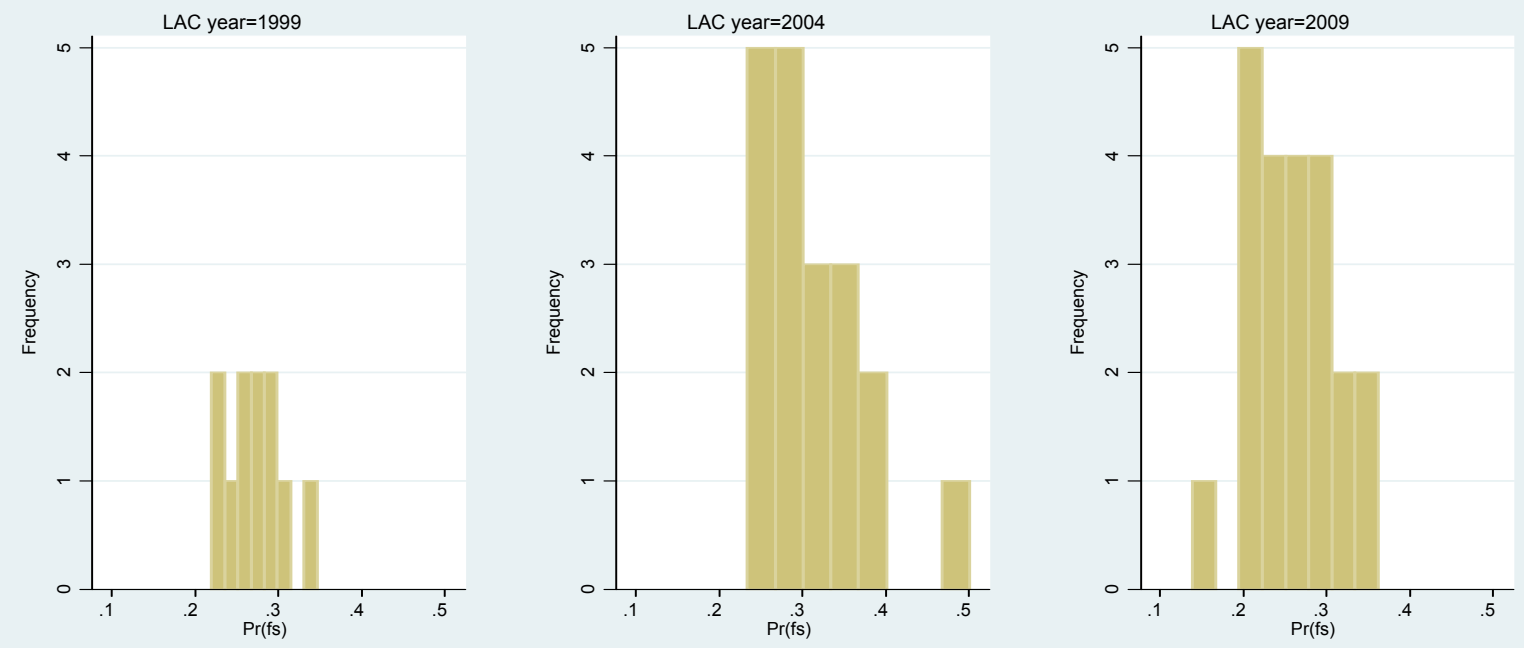
Figure 4: Distribution of probability of experiencing a fiscal stress event in MENAP countries
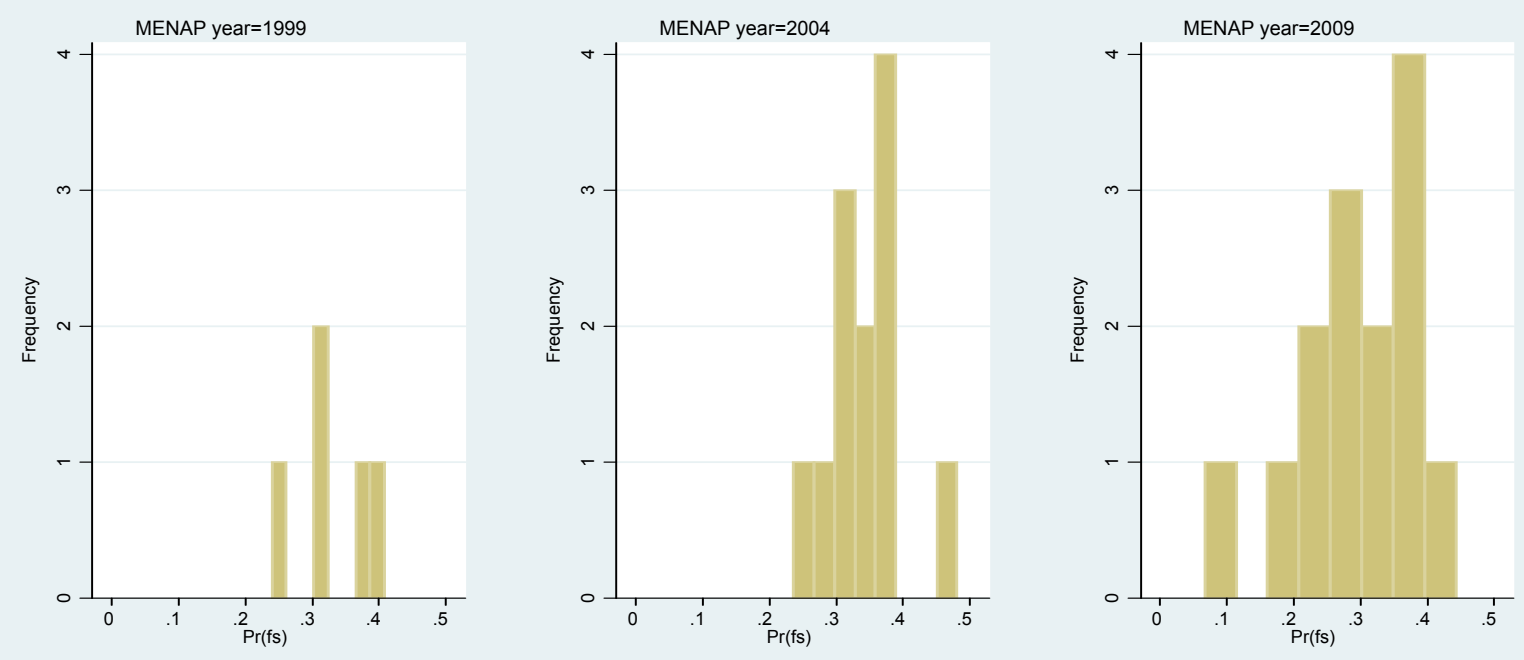

Figure 5: Distribution of probability of experiencing a fiscal stress event in SSA countries
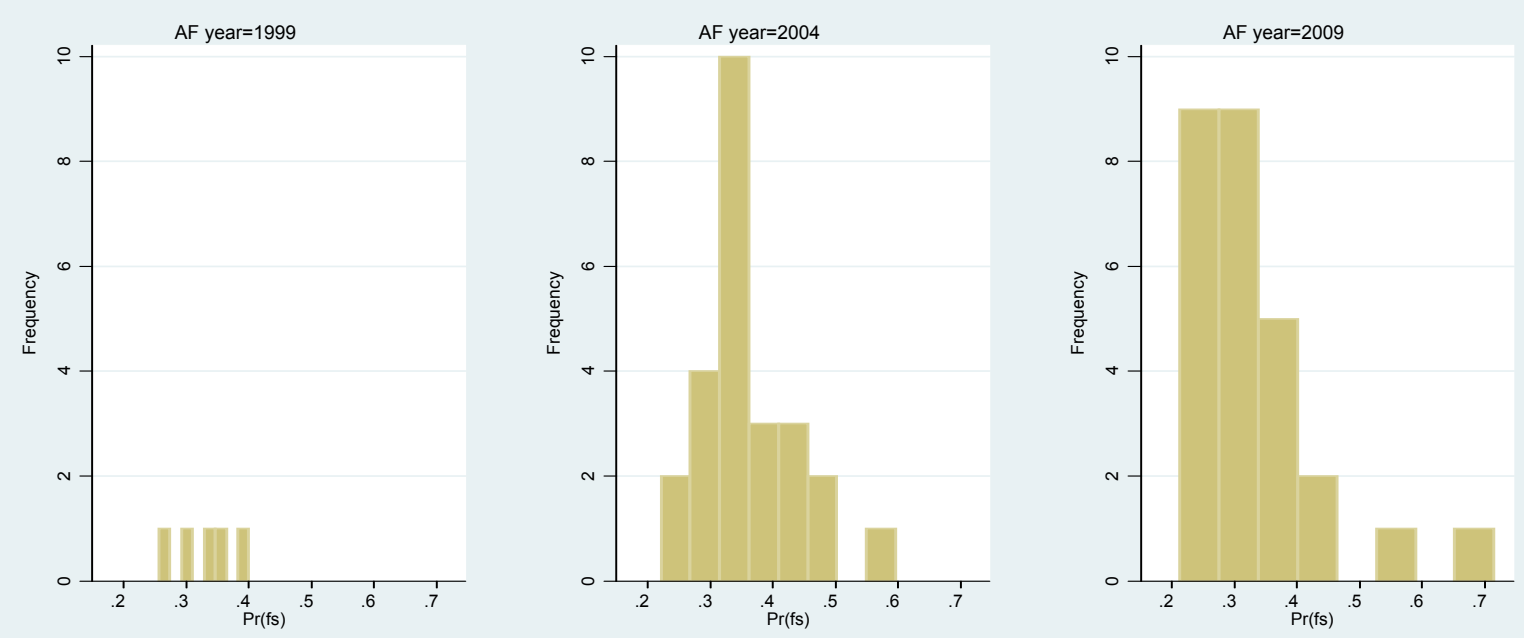

Figure 6: Distribution of probability of experiencing a fiscal stress event in advanced countries
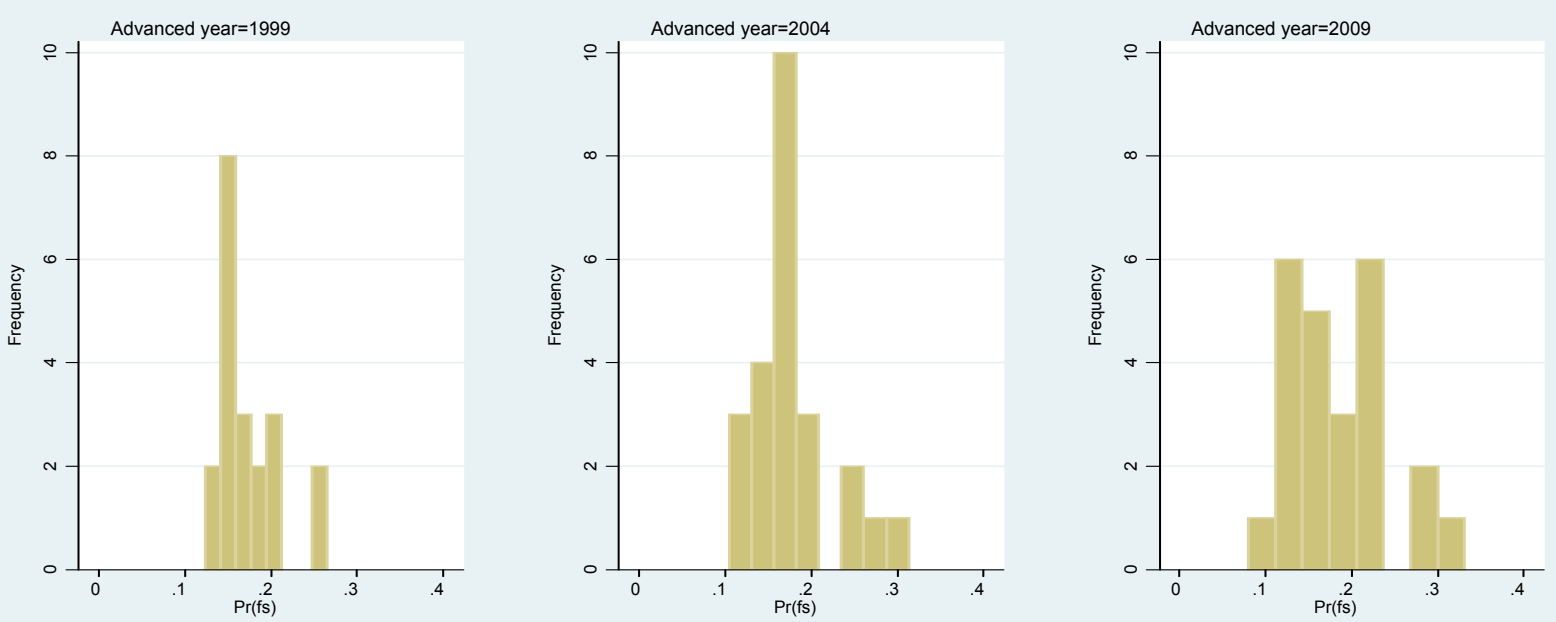
Figure 7: Distribution of probability of experiencing a political stress event in Asia-Pacific countries
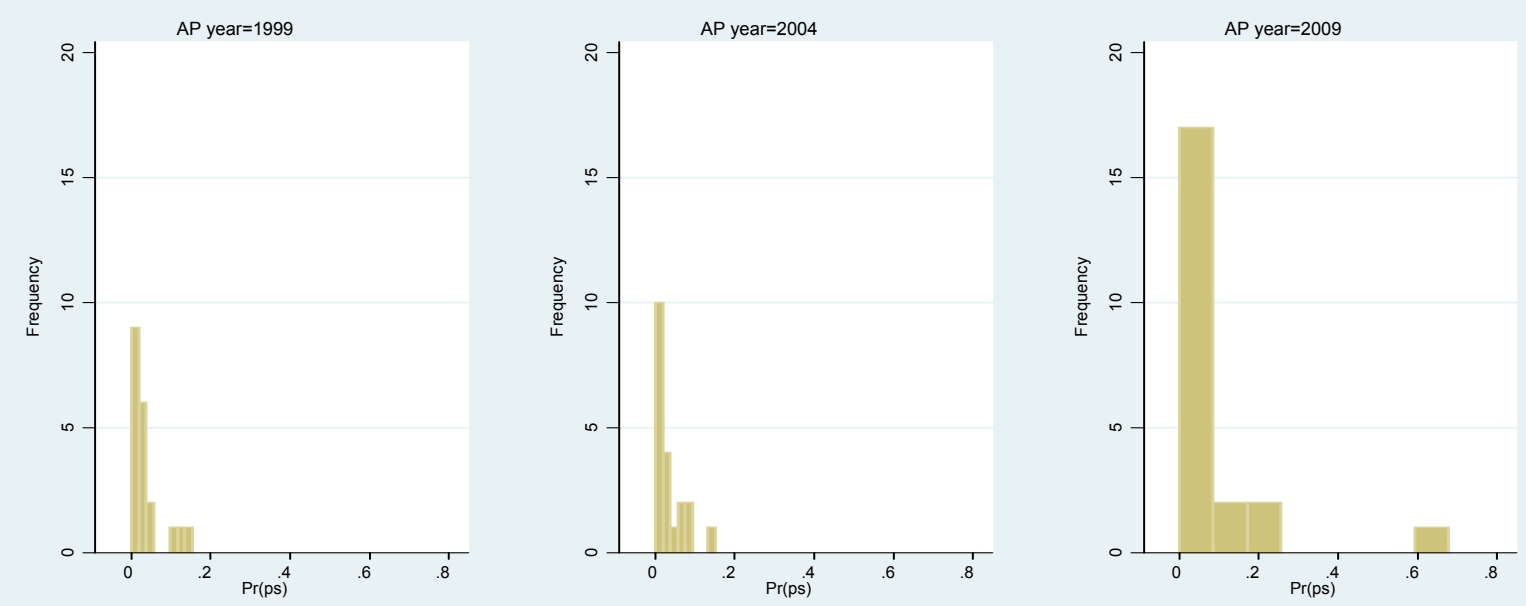

Figure 8: Distribution of probability of experiencing a political stress event in CEE countries
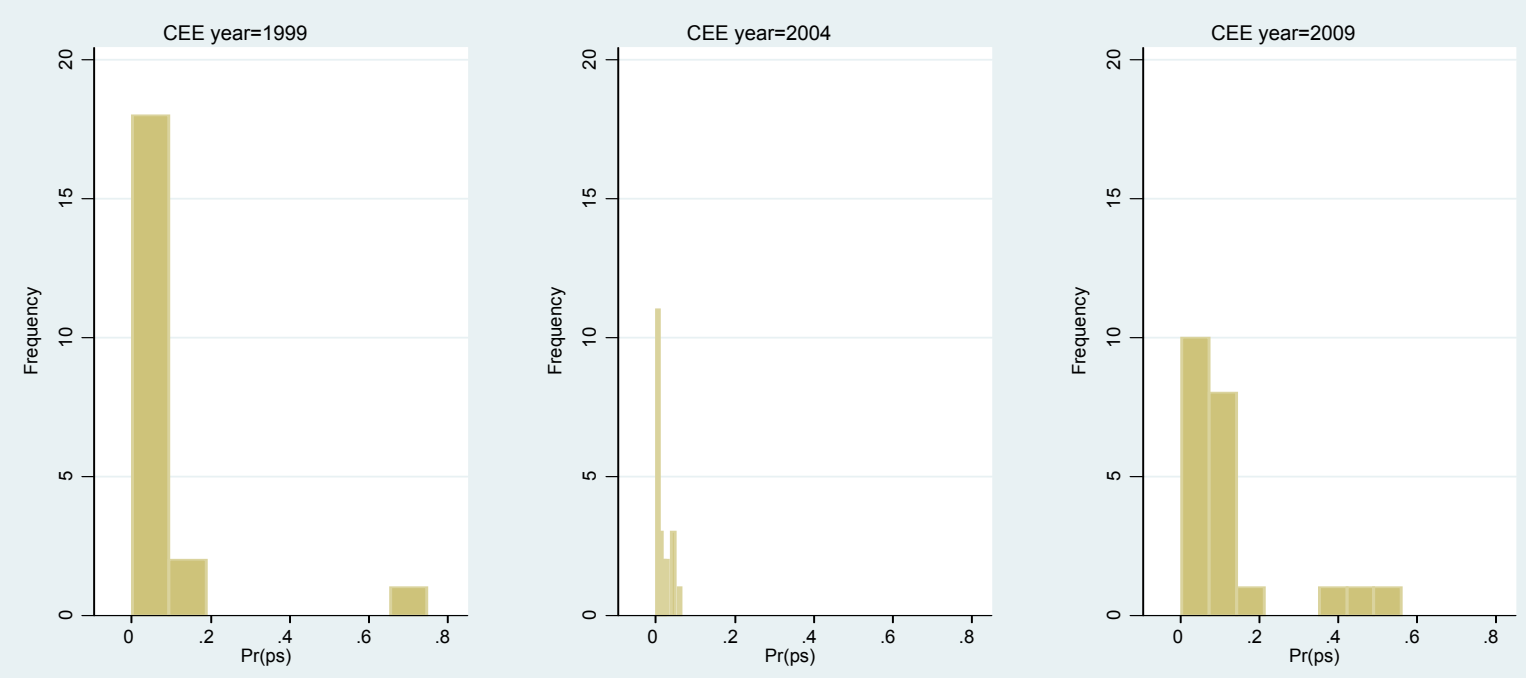

Figure 9: Distribution of probability of experiencing a political stress event in LAC countries
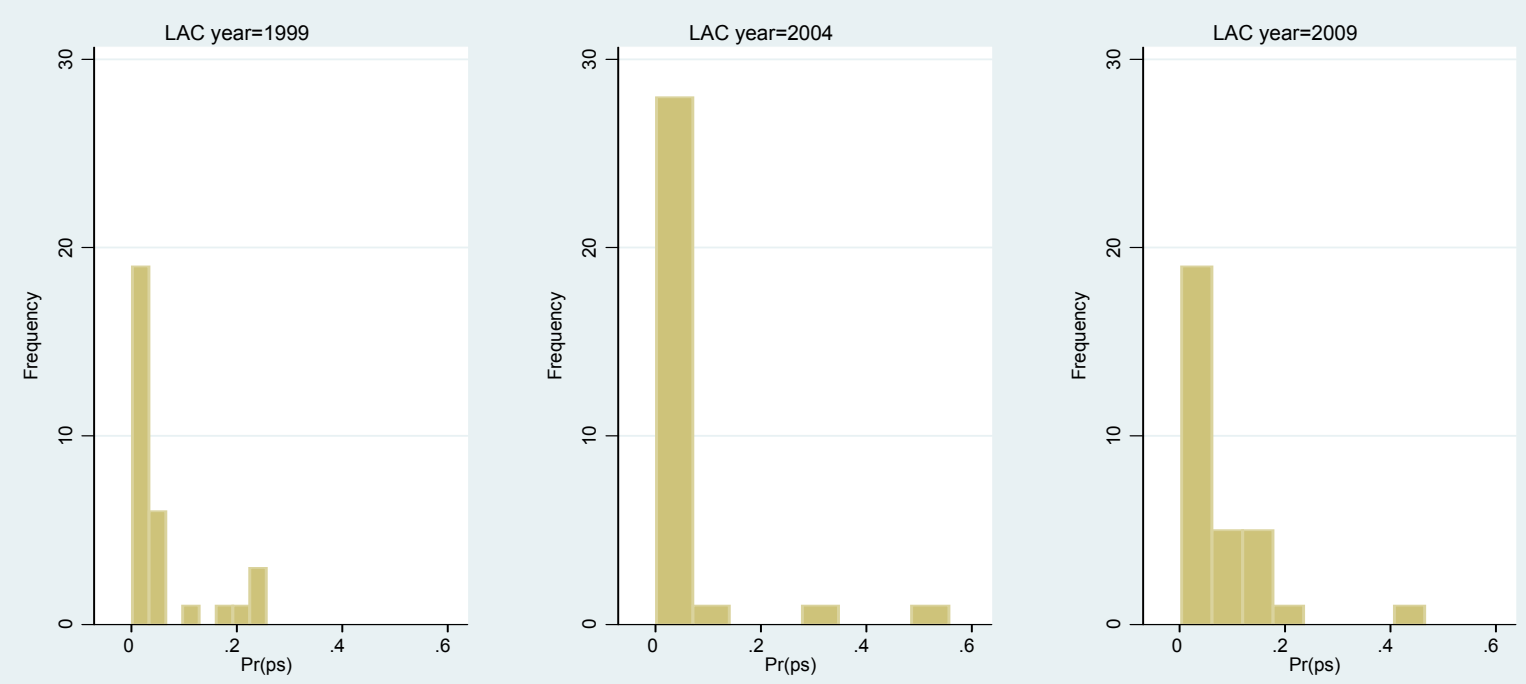
Figure 10: Distribution of probability of experiencing a political stress event in MENAP countries
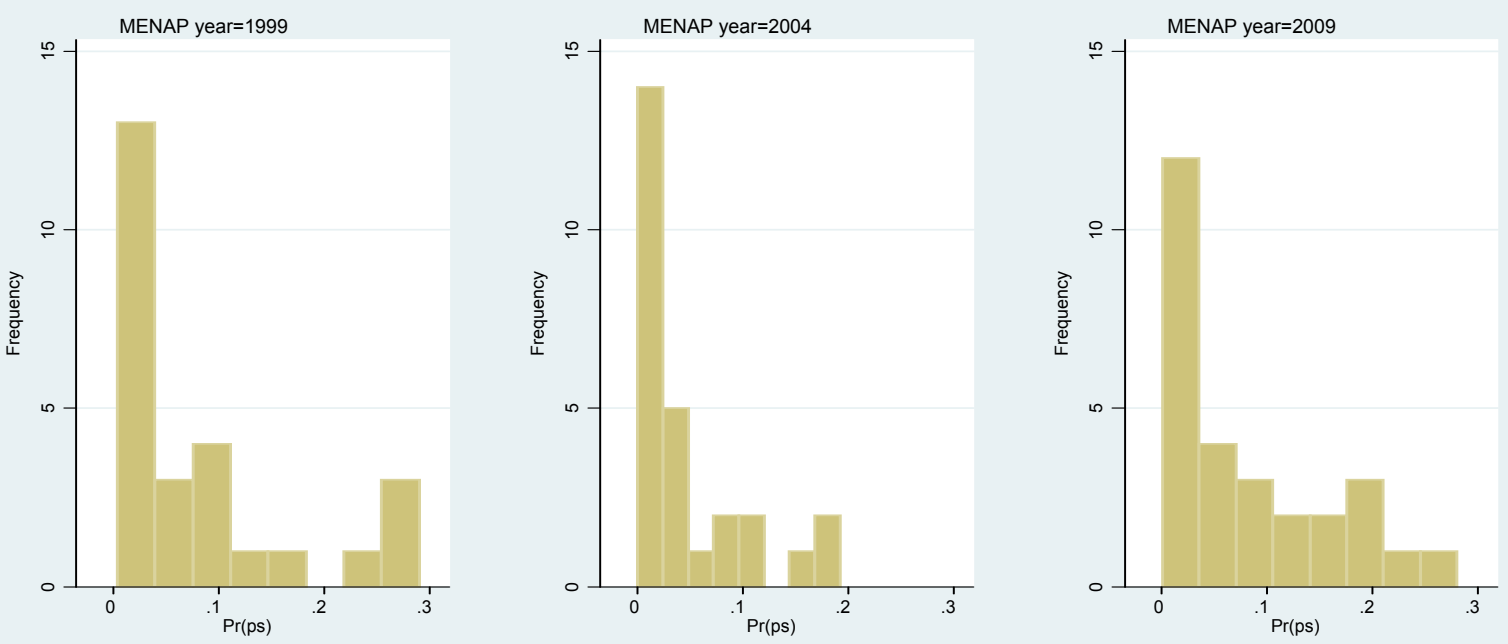

Figure 11: Distribution of probability of experiencing a political stress event in SSA countries
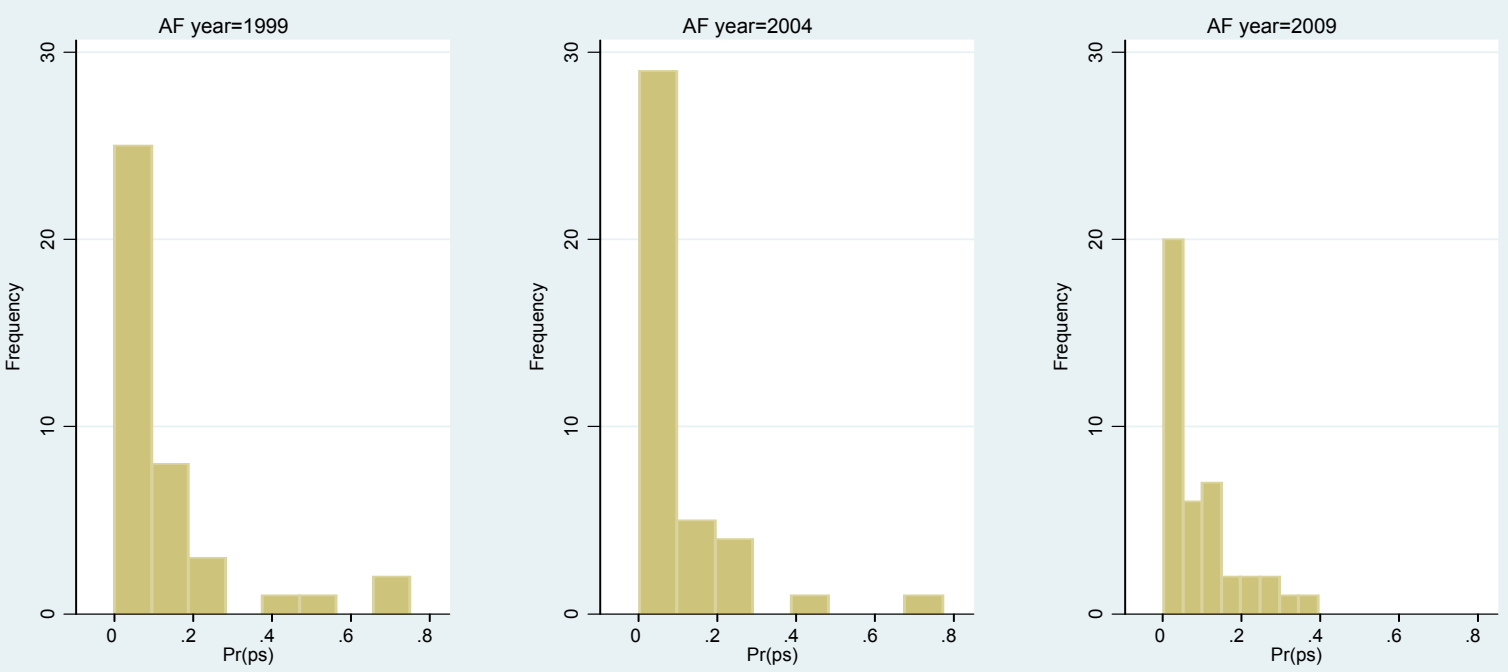

Figure 12: Distribution of probability of experiencing a political stress event in advanced countries
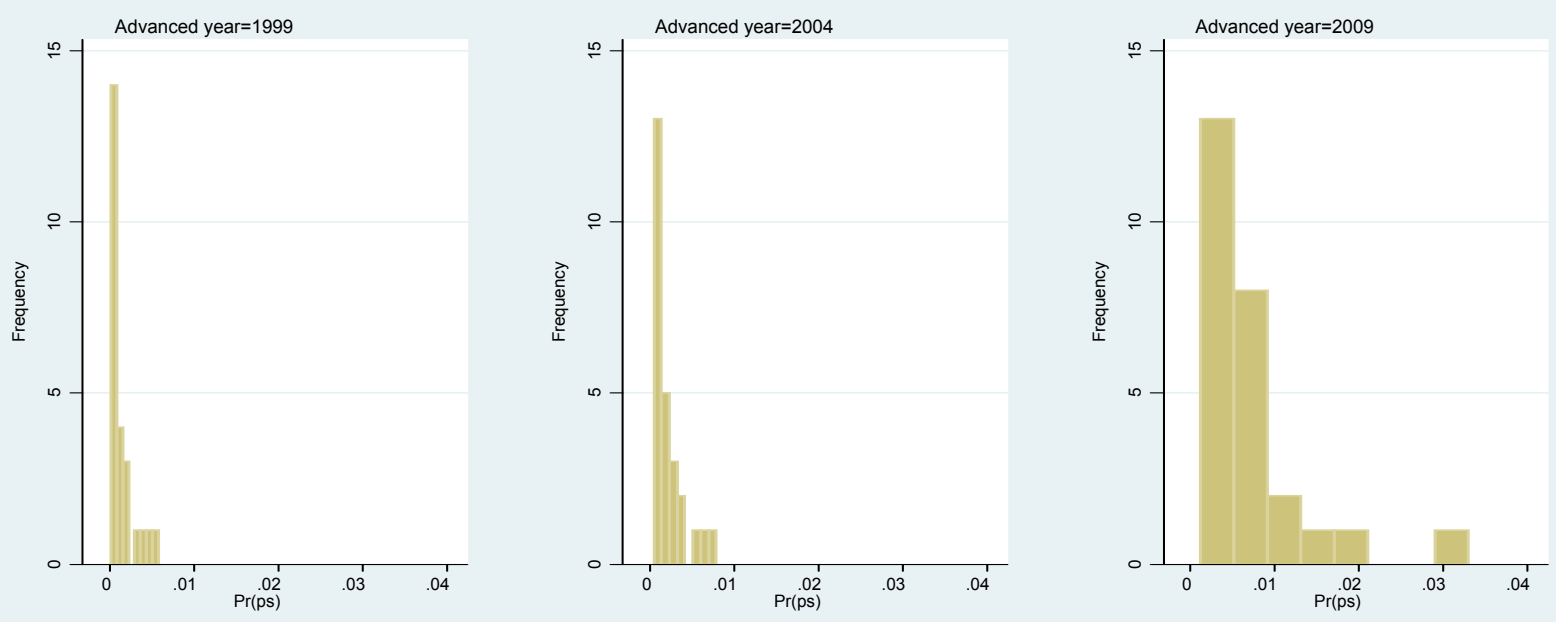